\title{
Research Square \\ Impact of the El Niño type and PDO on the winter sub-seasonal North American zonal temperature dipole via the variability of positive PNA patterns
}

\section{Yao Ge}

Institute of Atmospheric Physics Chinese Academy of Sciences

Dehai Luo ( $\square$ ldh@mail.iap.ac.cn )

RCE-TEA, Institute of Atmospheric Physics, Chinese Academy of Science

\section{Research Article}

Keywords: El Nino, PDO, PNA patterns

Posted Date: August 12th, 2021

DOl: https://doi.org/10.21203/rs.3.rs-484141/v1

License: (c) (1) This work is licensed under a Creative Commons Attribution 4.0 International License.

Read Full License 
4

\section{.} 17 18 9 0 1 22 23 24

\title{
variability of positive PNA patterns
}

\author{
Yao Ge and Dehai Luo
}

Key Laboratory of Regional Climate-Environment for Temperate East Asia, Institute of Atmospheric Physics, Chinese Academy of Sciences, Beijing 100029, China and College of Earth Sciences, University of Chinese Academy of Sciences, Beijing, China

Submitted to Climate Dynamics

Corresponding author: DehaiLuo,ldh@mail.iap.ac.cn 


\begin{abstract}
\end{abstract}
In recent years, the winter (from December to February, DJF) North American surface air temperature (SAT) anomaly in midlatitudes shows a "warm west/cold east" (WWCE) dipole pattern. To some extent, the winter WWCE dipole can be considered as being a result of the winter mean of sub-seasonal WWCE events. In this paper, the Pacific SST condition linked to the sub-seasonal WWCE SAT dipole is investigated. It is found that while the sub-seasonal WWCE dipole is related to the positive Pacific North American $\left(\mathrm{PNA}^{+}\right)$pattern, the impact of the $\mathrm{PNA}^{+}$on the WWCE dipole depends on the El Niño SST type and the phase of Pacific decadal Oscillation (PDO). For a central-Pacific (CP) type El Niño, the positive (negative) height anomaly center of $\mathrm{PNA}^{+}$is located in the west (east) part of North America to result in an intensified WWCE dipole, though the positive PDO favors the WWCE dipole. In contrast, the WWCE dipole is suppressed under an Eastern-Pacific (EP) type El Niño because the $\mathrm{PNA}^{+}$anticyclonic anomaly dominates the whole North America.

Moreover, the physical cause of why the type of El Niño influences the $\mathrm{PNA}^{+}$is further examined. It is found that the type of El Niño can significantly influence the location of $\mathrm{PNA}^{+}$through changing North Pacific midlatitude westerly winds (NPWWs). For the CP-type El Niño, the eastward migration of $\mathrm{PNA}^{+}$is suppressed to favor its anticyclonic (cyclonic) anomaly appearing in the west (east) region of North American owing to reduced NPWWs. But for the EP-type El Niño, NPWWs are intensified to cause the appearance of the $\mathrm{PNA}^{+}$anticyclonic anomaly over the whole North America due to enhanced Hadley cell and Ferrell cell. 


\section{Introduction}

In the recent decades, North American east experienced frequent severe cold extreme weathers. For example, 2013/14 and 2014/15 winters are characterized by warm and drought in California with a strong cold anomaly in the east of North America, whose temperature anomalies show a North American "warm west/cold east" (WWCE) dipole in midlatitudes (Wang et al .2014; Lee et al. 2015; Hartmann 2015; Singh et al. 2016). Such a temperature dipole pattern was expected to frequently occur in the future (Wang et al. 2017; Chien et al. 2019). Thus, the physical cause of the North American WWCE dipole has attracted a great interest of scientists and has been an important research topic in recent years (Wang et al. 2014, 2015; Seager et al. 2016; Lee et al. 2015; Yu and Zhang 2015; Hartmann, 2015; Yu et al. 2016, 17, 2018; Singh et al. 2016; Xie and Zhang 2017; Schulte and Lee 2017; B. Luo et al. 2020).

It has been recognized that the presence of the WWCE dipole in the North America in 2013/14 winter might be associated with the developing phase of El Niño (Wang et al. 2014, 2015). Seager and Henderson (2016) pointed out that the sea surface temperature (SST) anomaly pattern in the tropical Pacific and the south Indian Ocean might have contributed to California's drought during the 2013/14 winter. Hartmann (2015) suggested that the North American cold anomaly in the 2013/14 winter was related to the North Pacific mode (NPM) of the SST anomaly. On the other hand, Peng et al (2019) found that the abnormal atmospheric circulation related to the extreme climate on the North America for the 2013/14 winter was also influenced by the tropical Madden-Julian Oscillation (MJO). Lee et al. (2015) indicated that the low sea ice 
concentration in the Bering Sea has a large contribution to the WWCE dipole, even though some studies suggested that the westward shift of Greenland blocking due to the sea ice concentration decline in the west of Greenland can lead to such a WWCE dipole (Chen and Luo 2017, 2019). However, Xie and Zhang (2017) pointed out that the cold winter in $2014 / 2015$ is likely related to internal atmospheric variability, even though Peng et al. (2018) connected it to the effect of El Niño or NPM. More recently, B. Luo et al. (2020) found that the WWCE dipole not only depends on the North Pacific blocking, but also on the phase of the North Atlantic Oscillation (NAO), even though modulated by El Niño-Southern Oscillation (ENSO) and NPM. While the cold winter during 2013/14 (2014/15) is related to North Pacific Oscillation/West Pacific pattern (Baxter and Nigam 2015 or North Pacific blocking and NAO (B. Luo et al. 2020), whether the Pacific North American (PNA) influences the North American WWCE dipole is not clarified so far because the PNA is the main mode of atmospheric variability in the Pacific-North America sector (Hoskins and Karoly, 1981).

It has been recognized that the PNA has an important impact on the weather and climate over North America (Yu et al .2016; Harnik et al. 2016). Some studies have shown that the PNA as an atmospheric internal mode is modulated by the air-sea interaction (Straus and Shukla 2002, Peng 2014). On the other hand, Luo et al. (2020) found that the background winds could influence the period, spatial shape, movement and amplitude of the PNA, whereas the structure and strength of background winds are related to the SST anomaly pattern. Thus, the PNA can be influenced by the Pacific SST anomaly through the background condition change. While some studies have noted 
the effect of the PNA on the air temperature anomaly over North America (Harnik et al. 2016), what type of Pacific SST condition favors or suppresses the $\mathrm{PNA}^{+}$leading to a strong North American WWCE SAT dipole is not clear so far. Thus, examining under what SST condition the $\mathrm{PNA}^{+}$can lead to a North American WWCE dipole has an important implication in understanding and predicting cold extreme weathers over the North America, which is the main purpose of our present paper.

This paper is arranged as follows. The data and method are described in Section 2. In Section 3, atmospheric circulation patterns during the 2013/14 and 2014/15 winters are presented to establish the relationship of North American SAT anomaly with the phase of PNA. The different weather regimes of $\mathrm{PNA}^{+}$events and their connection to the type of El Niño are investigated in Section 4. In this section, we also explore why the type of El Niño can cause a large change of $\mathrm{PNA}^{+}$. In Section 5, we examine a connection of the WWCE dipole to the combined effect of the CP-type El Niño and PDO. The conclusions and discussion are given in the final section.

\section{Data and method}

The reanalysis data in winter (from December to February, DJF) used in this study is taken from the National Centers for Environmental Prediction-National Center for Atmospheric Research (Kalnay et al. 1996) from December 1950/February 1951 to December 2018/February 2019 (1950-2018, hereafter). This dataset includes the daily mean 500-hPa geopotential height (Z500) and surface air temperature (SAT) as well as the monthly horizonal (zonal and meridional components $\mathrm{U}$ and $\mathrm{V}$ ) field with $2.5^{\circ} \times 2.5^{\circ}$ grids. For the winter SST anomaly, we used the monthly-mean sea surface temperature 
114 (SST) dataset with $1^{\circ} \times 1^{\circ}$ grids resolution taken from the Hadley Centre (Rayner et al.

2003) from 1950-2018. All the anomalies at each grid were obtained by removing the seasonal cycle and linear trend.

Furthermore, we used the daily PNA index provided by the NOAA Climate Prediction Center (https://www.cpc.ncep.noaa.gov/), which is obtained based on the Rotated Empirical Orthogonal Function (REOF or rotated EOF) of 500-mb height anomalies. Here, a $\mathrm{PNA}^{+}\left(\mathrm{PNA}^{-}\right)$event is defined if the daily PNA index is above 1.25 (below -1.25) standard deviations (STDs) for at least three consecutive days. During the life cycle of PNA, lag 0 denotes the peak day of the PNA event. In the following discussions, we calculate the time-mean composite daily Z500 and SAT anomalies averaged from lag - 5 to 5 days of individual PNA events to reflect the contribution of the mature PNA to the SAT anomaly over the North America. But the temporal variations of the composite daily SAT anomalies averaged over the east and west parts of the North America and the composite daily warm west/cold east SAT dipole of PNA events are presented for the entire PNA event lifetime (from lag -10 to 10 days) because the PNA event is of two weeks (10-20 days) (Feldstein 2002).

Here, we also used a combined regression-EOF procedure as in Kao and $\mathrm{Yu}$ (2009) to classify the El Niño-Southern Oscillation (ENSO) into CP- and EP-types. We subtracted the SST anomalies regressed with the Niño1+2 index in the eastern equatorial Pacific $\left(10^{\circ} \mathrm{S}-0,80^{\circ}-90^{\circ} \mathrm{W}\right)$ from the original SST anomalies and then used the EOF analysis to obtain the CP-ENSO structure of the subtracted SST anomalies. Similarly, the EOF analysis of the SST anomalies regressed onto the Niño 4 index in 
the central Pacific region $\left(5^{\circ} \mathrm{S}-5^{\circ} \mathrm{N}, 160^{\circ} \mathrm{E}^{\circ}-150^{\circ} \mathrm{W}\right)$ and subtracted from the original

SST anomalies is performed to obtain the EP-type ENSO structure. In this case, the principal component (PC1) time series of the first empirical orthogonal function (EOF1) of the DJF-mean SST anomaly for a CP-type (EP-type) El Niño is defined as the CPtype (EP-type) El Niño index. The SST anomaly averaged over the region $\left(10^{\circ} \mathrm{S}-0\right.$ and $\left.80^{\circ}-90^{\circ} \mathrm{W}\right)$ or the region $\left(5^{\circ} \mathrm{S}-5^{\circ} \mathrm{N}\right.$ and $\left.160^{\circ} \mathrm{E}^{\circ}-150^{\circ} \mathrm{W}\right)$ is defined as the Niño $1+2$ or Niño 4 index respectively. Moreover, the winter Pacific decadal Oscillation (PDO) index was defined as the PC1 time series of the EOF1 mode of DJF-mean SST anomalies over the North Pacific $\left(120^{\circ} \mathrm{E}-120^{\circ} \mathrm{W}, 20^{\circ}-70^{\circ} \mathrm{N}\right)$ as in Ding et al. (2015).

In this paper, we used the k-means clustering method as used in Michelangeli et al., (1995), Ferranti et al., (2015) and Champagne et al., (2019) to classify the different regimes of sub-seasonal SAT and Z500 anomalies over North America $\left(25^{\circ} \mathrm{N}-70^{\circ} \mathrm{N}\right.$, $\left.140^{\circ} \mathrm{W}-60^{\circ} \mathrm{W}\right)$ for $\mathrm{PNA}^{+}$events during the $1950-2018$. Using such a method can help us to identify what types of $\mathrm{PNA}^{+}$patterns favor the WWCE dipole over North America. The k-means clustering algorithm was constructed by minimizing the sum of the squares of distances between each sample and the corresponding cluster centroid based on an iterative process, in which the Euclidean distance was used. The detail of this clustering method can be found in Michelangeli et al. (1995).

3. Winter North American warm west/cold east dipole and its link to the phase of PNA

a) Case analysis of 2013/14 and 2014/15 winters

The winters of 2013/14 and 2014/15 are two typical examples of the warm 
west/cold east SAT anomaly over the North America widely analyzed in previous studies (Wang et al. 2014, Lee et al. 2015; Hartmann 2015; Yu and Zhang 2015; Peng et al. 2018; B. Luo et al. 2020). We first analyzed the two winters to motivate our present study. Figures 1a-b show the DJF-mean Z500 and SAT anomalies during 2013/14 and $2014 / 15$, whereas the daily variations of the corresponding zonal SAT dipole index, as defined by $\mathrm{T}_{\mathrm{WE}}=\mathrm{T}_{\mathrm{W}}-\mathrm{T}_{\mathrm{E}}$, and the PNA index from December to February are shown in

Fig.1c-f. In the $\mathrm{T}_{\mathrm{WE}}$ index, $\mathrm{T}_{\mathrm{W}}$ and $\mathrm{T}_{\mathrm{E}}$ represent the domain-averaged SAT anomaly over the west ( $\left.\mathrm{T}_{\mathrm{W}}: 25^{\circ} \mathrm{N}-55^{\circ} \mathrm{N}, 130^{\circ} \mathrm{W}-100^{\circ} \mathrm{W}\right)$ and east $\left(\mathrm{T}_{\mathrm{E}}: 25-55^{\circ} \mathrm{N}, 100^{\circ} \mathrm{W}-65^{\circ} \mathrm{W}\right)$ parts of North America, respectively. The positive value of $\mathrm{T}_{\mathrm{WE}}$ could reflect a WWCE dipole over North America when the $\mathrm{Tw}>0$ and $\mathrm{T}_{\mathrm{E}}<0$. It is noted that the winter-mean SAT anomaly shows an intense WWCE dipole along the zonal direction of North American mid-latitudes during 2013/14 (Fig. 1a) and 2014/15 (Fig. 1b) winters. In the two winters, an anticyclonic anomaly appears over the North American west coast, whereas a cyclonic anomaly is located in the east part of North America. It is also found from the wavelet power spectrum analysis that the timescale of the $\mathrm{T}_{\mathrm{WE}}$ variation is about 20 days (Figure S1 in the supplementary file), crudely consistent with the lifetime of the PNA events (Feldstein 2002). In particular, we can see from the daily variation of $\mathrm{T}_{\mathrm{WE}}$ during 2013/14 and 2014/15 winters that $\mathrm{PNA}^{+}$corresponds to a strong sub-seasonal WWCE dipole over North America (Fig. 1c-f). However, the daily evolution of the PNA index in Figs. 1e-f shows that the WWCE SAT dipole during 2013/14 is also related to PNA'. Below, we further evaluate the importance of the PNA in the generation of the WWCE dipole. 
It is easy to find that there are $1 \mathrm{PNA}^{+}$and $2 \mathrm{PNA}^{-}\left(1 \mathrm{PNA}^{+}\right)$events during the 2013/14 (2014/15) winter according to the above definition of an individual PNA event. To identify the contribution of PNA to the DJF-mean WWCE SAT anomaly, Figure 2 shows the DJF-mean Z500 and SAT anomaly fields with and without PNA events during the 2013/14 and 2014/15 winters and their differences (the case without PNA events represents that all the days from lag -10 to 10 of PNA events are removed, where lag 0 denotes the peak day of PNA). It is found that the North American mid-latitude WWCE dipole patterns during the 2013/14 and 2014/15 winters (Figs. 2c, f) are related to PNA events (Figs.1e-f). In fact, the high latitude cold anomaly in the two winters are also related to positive NAO $\left(\mathrm{NAO}^{+}\right)$events (Figs. 2b, e), even though a high latitude North Pacific blocking occurs during the 2014/15 winters. The role of North Pacific blocking and $\mathrm{NAO}^{+}$in the North American WWCE dipole has been discussed in B. Luo et al. (2020). Thus, in this paper we do not examine the effect of $\mathrm{NAO}^{+}$and North Pacific blocking on the winter SAT anomaly over the North America. Instead, we examine the impact of individual PNA events on the North American WWCE SAT dipole. Here, we used $p=\frac{T_{W E}(P N A)}{T_{W E}(D J F)} \times 100 \%$ to calculate the contribution of the PNA to the winter WWCE SAT dipole, where $\mathrm{T}_{\mathrm{WE}}(\mathrm{PNA})$ represents the total days of $\mathrm{T}_{\mathrm{WE}}>0$ from lag-10 to 10 for PNA events and $\mathrm{T}_{\mathrm{WE}}$ (DJF) denotes the total days of $\mathrm{T}_{\mathrm{WE}}>0$ in winter. It is found that the contribution of PNA to the winter WWCE dipole is about $61.1 \%$ during $2013 / 14$ or $46.3 \%$ during $2014 / 15$. Thus, the PNA can influence the winter WWCE dipole via the generation of sub-seasonal WWCE dipole. Below, we will focus our attention on examining under what background condition the PNA can lead 
to an intense WWCE dipole because the PNA is varied with the background condition change.

To understand the different contributions of $\mathrm{PNA}^{-}$and $\mathrm{PNA}^{+}$to the WWCE dipole in the 2013/14 and 2014/15 winters, it is useful to show the time-mean daily Z500 and SAT anomalies averaged from lag - 5 to 5 days of $\mathrm{PNA}^{-}$and $\mathrm{PNA}^{+}$events in Figs. 3a-d during the two winters. It is found that during the 2013/14 winter the $\mathrm{PNA}^{-}$resembles a high latitude North Pacific blocking and corresponds to an intense cold anomaly over the whole North American mid-high latitude region (Fig. 3a). Its combination with the $\mathrm{PNA}^{+}$(Fig. 3b) can produce an intense WWCE dipole over North America (Fig.3c). For this case, the $\mathrm{PNA}^{+}$does not correspond to a strong cold anomaly in the east part of North America (Fig.3b). However, during the 2014/15 winter the $\mathrm{PNA}^{+}$can correspond

213 to an intense WWCE dipole (Fig.3d). Using $p=\frac{T_{W E}(P N A)}{T_{W E}(D J F)} \times 100 \%$, it is estimated that the contribution of the $\mathrm{PNA}^{+}$to the winter WWCE SAT dipole during the 2013/14 $(2014 / 15)$ winter is about $29.1 \%(46.3 \%)$, indicating that the $\mathrm{PNA}^{+}$has a larger contribution to the winter North American WWCE SAT dipole during the 2014/15 winter than during the 2013/14 winter. This suggests that the effect of the $\mathrm{PNA}^{+}$on the North American SAT anomaly exhibits a significant interannual variability. Because the PNA- cannot correspond to a typical WWCE SAT dipole over North America, our emphasis in the following discussion is mainly placed on examining the effect of the varying $\mathrm{PNA}^{+}$on the North American WWCE dipole. 
is likely related to a cold SST anomaly in the tropical region (Fig.3e) and a negative PDO ( (DO- $^{-}$) phase with a value of -0.5 STDs as noted below. But during the 2014/15 winter a strong WWCE dipole can be seen even for the $\mathrm{PNA}^{+}$(Fig. 3d), which is associated with El Niño and a positive PDO $\left(\mathrm{PDO}^{+}\right)$positive with a value of 1.7 STDs (Fig. 3f). Thus, it is suggested that the contribution of the $\mathrm{PNA}^{+}$to the North American WWCE dipole might be related to the different SST anomaly patterns via the background condition change, even though the $\mathrm{PNA}^{+}$is driven by the internal atmospheric variability such as synoptic-scale eddy activity (Luo et al. 2020).

\section{b) Composite result of $P N A^{+}$events}

Here, the WWCE dipole for each day is defined as an instantaneous daily WWCE dipole event if the value of $\mathrm{T}_{\mathrm{WE}}$ is above 1.0 STDs for $\mathrm{TW}_{\mathrm{W}}>0$ and $\mathrm{T}_{\mathrm{E}}<0$ in the west and east domains of North America as shown in Figure 4a. Figures 4 b-c show the winter frequency (total day number) of daily WWCE events and the composite SAT and Z500 anomaly fields for all days of daily WWCE events during the winters from 1950 to 2018. It is seen that the Z500 anomaly mainly shows a wave train structure similar to a zonally oriented $\mathrm{PNA}^{+}$pattern, thus indicating that the $\mathrm{PNA}^{+}$pattern might play a role in the WWCE dipole. As noted below, the $\mathrm{PNA}^{+}$can become a zonal wave train structure under certain conditions, even though it is not a typical PNA structure.

To further understand whether the $\mathrm{PNA}^{+}$can lead to a strong WWCE dipole over North America, we show the time series of the event numbers of individual $\mathrm{PNA}^{+}$ events during 1950-2018 in Fig.5a. Statistical calculation shows that there are $79 \mathrm{PNA}^{+}$ events during 1950-2018. Figure 5b shows the corresponding time-mean fields of 
composite daily Z500 and SAT anomalies averaged from lag - 5 to 5 days for the $\mathrm{PNA}^{+}$ events, which represents a typical $\mathrm{PNA}^{+}$pattern. It is seen that there is a warm anomaly in the northwest side of North America for the $\mathrm{PNA}^{+}$(Fig. 5b) because its anticyclonic anomaly exists over the northwest North America. But a weak cold anomaly can be seen over the southeastern North America. The variation of composite daily $\mathrm{T}_{\mathrm{WE}}$ index from the lag-10 to 10 days of PNA events (Fig. 5 c) also indicates that a relatively weak WWCE SAT dipole can be formed over North America for the PNA ${ }^{+}$. However, as we will find below, the varied $\mathrm{PNA}^{+}$can lead to a strong typical WWCE dipole under certain SST conditions.

a) Preferred regime patterns of the positive PNA associated with the WWCE dipole WWCE dipole, it is useful to use a k-means clustering method as widely used in previous studies (e. g., Michelangeli et al., 1995; Champagne et al. 2019) to classify time-mean SAT anomalies averaged from lag-5 to 5 days over the North America $\left(25^{\circ} \mathrm{N}-70^{\circ} \mathrm{N}, 140^{\circ} \mathrm{W}-60^{\circ} \mathrm{W}\right)$ associated with the $\mathrm{PNA}^{+}$events. For $79 \mathrm{PNA}^{+}$events during 1950-2018 winters, the time-mean SAT anomalies associated with the $\mathrm{PNA}^{+}$ events can be classified into six clustering regimes: $\mathrm{C} 1, \mathrm{C} 2, \mathrm{C} 3, \mathrm{C} 4, \mathrm{C} 5$ and $\mathrm{C} 6$. By compositing daily Z500 and SAT anomalies associated with the six clustering regimes, one can find the preferred regime pattern of the $\mathrm{PNA}^{+}$associated with the typical WWCE dipole. 
Figure 6 shows time-mean fields of composite daily Z500 and SAT anomalies averaged from lag -5 to 5 days of the $\mathrm{PNA}^{+}$events related to six clustering regimes $(\mathrm{C} 1$, $\mathrm{C} 2, \mathrm{C} 3, \mathrm{C} 4, \mathrm{C} 5$ and $\mathrm{C} 6$ ). It is found that $\mathrm{C} 3$ resembling a zonal wave train structure with an anticyclonic (cyclonic) anomaly in the west (east) part of the North America corresponds to a typical WWCE dipole (Fig. 6c), whereas a strong WWCE dipole also occurs for C6 (Fig. 6f) and is associated with the $\mathrm{PNA}^{+}$concurrent with the negative Arctic Oscillation ( $\mathrm{AO}^{-}$). Only a weak WWCE dipole takes place for C4 (Fig. 6d). A typical WWCE dipole cannot occur over North American midlatitudes for C1 (Fig. 6a), C2 (Fig. 6b) and C5 (Fig. 6e), while a cold anomaly appears over the whole North America midlatitudes for C2 (Fig. 6b). Through a comparison with Figs. 3a-d, we can see that C3 looks like the $\mathrm{PNA}^{+}$pattern in the $2014 / 15$ winter (Fig. 3d) in that they have a pattern correlation coefficient of 0.73 in the region $\left(150^{\circ} \mathrm{E}-30^{\circ} \mathrm{W}, 20^{\circ}-80^{\circ} \mathrm{N}\right)$. In the six clustering regimes, the $\mathrm{C} 4$ regime is most frequent (Fig. 6d) and resembles a typical $\mathrm{PNA}^{+}$pattern (the composite result of all the $\mathrm{PNA}^{+}$events in Fig. $5 \mathrm{~b}$ ) because its pattern correlation coefficient with Fig. $5 \mathrm{~b}$ is nearly 0.95 . Figure 7 shows the time series of the event numbers of $\mathrm{PNA}^{+}$events for each one of the six clustering regimes during 19502018. It is interesting to see that $\mathrm{C} 3, \mathrm{C} 4$ and $\mathrm{C} 5$ regimes show notable interannual and decadal variability (Figs. 7c, d, e), whereas the $\mathrm{C} 6(\mathrm{C} 1)$ regime takes place mainly during the 1950-1981 (1994-2018) winters (Figs. 7a, f). Thus, we can see from Fig. 7 that the PNA ${ }^{+}$event in the 2014/15 (2013/14) winter belongs to the C3 (C4) type. This indicates that although the $\mathrm{PNA}^{+}$is an internal mode, it has different spatial patterns. To further quantify which of the six clustering regimes favors the North American 
WWCE dipole, the temporal variations of $\mathrm{T}_{\mathrm{WE}}$ during the life cycle of $\mathrm{PNA}^{+}$(from lag10 to 10 days) are shown in Figure 8 for the six clustering regimes of the $\mathrm{PNA}^{+}$. It is found that in the six clustering regimes, the WWCE dipole is strongest during the $\mathrm{PNA}^{+}$ life cycle for $\mathrm{C} 3$. Thus, $\mathrm{C} 3$ is an optimal $\mathrm{PNA}^{+}$pattern that promotes a typical WWCE dipole. Although C4 and C6 correspond to WWCE dipoles respectively, C6 mainly appears before 1990. Furthermore, we show the correlation coefficients between the WWCE dipole index (Fig. 4b) and the event number of each clustering regime (Fig. 7) in Table 1. It is noted that C3 (C4) shows a significant positive correlation of $0.41(0.34)$ $(p<0.05)$ with the WWCE dipole index. Below, we will examine what type of SST conditions is responsible for $\mathrm{C} 3$ and $\mathrm{C} 4$.

\section{b) Pacific SST anomaly patterns linked to different clustering regimes}

Yu et al. (2012a, b) found from observation and numerical model that the spatial shape of extratropical atmospheric response to tropical Pacific SST anomalies depends on the type of ENSO. In other words, the $\mathrm{PNA}^{+}$pattern may be different as the Pacific SST anomaly condition is different. To establish the linkage of the six clustering regimes with different Pacific SST anomaly patterns, we show the composite DJF-mean SST anomalies of the six clustering regimes in Figure 9. It is seen that the Pacific SST anomalies related to $\mathrm{C} 1, \mathrm{C} 3, \mathrm{C} 4, \mathrm{C} 5$ and $\mathrm{C} 6$ regimes have the footprint of the ENSO or PDO. In particular, C3 (C5) corresponds to a typical CP-type (EP-type) El Niño in addition to $\mathrm{C} 3$ having a $\mathrm{PDO}^{+}$-like SST signal (Figs. 9c, e). The correlation coefficients shown in Table 2 indicate that $\mathrm{C} 3(\mathrm{C} 4)$ has modest significant positive correlations of 0.22 and $0.29(0.22$ and 0.22$)(\mathrm{p}<0.1$ for 0.22 and $\mathrm{P}<0.05$ for 0.29$)$ with the $\mathrm{CP}$ and 

a significant positive correlation of $0.29(0.37)(\mathrm{p}<0.05)$ with the EP El Niño index. Thus, the WWCE dipole associated with C3 is related to the CP-type El Niño (Fig. 9c). This result leads us to infer that the different types of El Niño might be an important factor influencing the WWCE dipole through the change of the $\mathrm{PNA}^{+}$pattern.

Figure 10a (10b) shows the spatial structure of the winter SST EOF1 anomaly for the CP-type (EP-type) El Niño when the value of the PC1 time series in Figs. 10c-d is is above 0.5 STDs. It is found that there are 12 CP-type El Niño winters (0.3/year) during 1950-1989, but 11 winters (0.38/year) during 1990-2018. Thus, the CP-type El Niño has slightly increased since 1990, consistent with the previous results (Kao and Yu 2009; Kug et al. 2009; Lee and McPhaden 2010; Yu et al. 2012a). Many studies have indicated that the different spatial pattern of the North American SAT anomaly in the CP- or EP-type El Niño winter might be associated with the wave trains in response to tropical convection anomalies (Peng et al. 2018). It is useful to show the time-mean composite daily Z500 and SAT anomalies averaged from lag -5 to 5 days associated with $\mathrm{PNA}^{+}$events in the CP- and EP-type El Niño winters in Figs.10e-f. It is noted that in the CP-type El Niño winter the $\mathrm{PNA}^{+}$resembling a zonal midlatitude wave train (Fig. S2) like C3 can produce an intense WWCE dipole over North America (Fig. 10e). But such a WWCE dipole is hardly seen for the EP-type El Niño winter (Fig.10f) because the anticyclonic anomaly of the $\mathrm{PNA}^{+}$like C5 almost occupies the whole North America. Thus, it is suggested that whether the $\mathrm{PNA}^{+}$leads to a strong North American 
WWCE dipole depends on whether the El Niño is the CP-type or not.

\section{c). Physical mechanism of the CP-and EP-type El Niño SSTs influencing the PNA ${ }^{+}$}

Here, we further examine why the CP- and EP-type El Niño SSTs have different influences on the $\mathrm{PNA}^{+}$, even though $\mathrm{C} 3$ of the $\mathrm{PNA}^{+}$patterns correspond to a zonal wave train structure. Because the variation of PNA depends on the change of the background zonal wind field (Luo et al. 2020), we could infer that the type of El Niño can influence the $\mathrm{PNA}^{+}$probably through changing background zonal winds over North Pacific midlatitudes due to the change of the winter meridional circulation (Hadley and Ferrell cells). The mass stream function (MSF) is an efficient method that represents the change of the winter meridional circulation (Feng and Li, 2013). The MSF can be written in the form of $\psi=\int \frac{2 \pi a \cos \phi}{g}[\bar{v}] d p$, where $[\bar{v}]$ is DJF-mean meridional wind averaged over $150^{\circ} \mathrm{E}-120^{\circ} \mathrm{W}, a$ is the earth's radius, $\mathrm{p}$ denotes the pressure in the vertical direction and $\phi$ represents the latitude with the gravitational acceleration being denoted by $g$. When there is $\psi>0$ in the region from the tropic to subtropic, it represents a Hadley cell. But, when $\psi<0$ in the region from the subtropic to midlatitudes, it can represent a Ferrell cell.

We show the height-latitude profiles of the DJF-mean MSF anomalies averaged over $150^{\circ} \mathrm{E}-120^{\circ} \mathrm{W}$ and the horizontal fields of DJF-mean U500 anomalies for PNA events excluded in Fig. 11 for the CP- and EP-type El Niño winters. It is found that the local Hadley cell is expanded northward for the CP-type El Niño (Fig. 11a), but intensified for the EP-type El Niño (Fig.11b). The Ferrell cell is stronger during the EPtype El Niño (Fig. 11b) than during the CP-type El Niño (Fig.11a), as further seen from 
their difference (Fig.11c). At the same time, the enhanced Ferrell cell is displaced more south for the EP-type El Niño than for the CP-type El Niño. The enhanced Hadley cell during the EP-type El Niño winter is shown to be related to enhanced convection in the central-east tropical Pacific associated with enhanced upward motions and enhanced poleward divergent wind anomalies in the subtropical Pacific (Fig.S3), as noted in Feng et al. (2017) by calculating the vertical velocity, divergent wind and Rossby wave source. Moreover, the CP and EP types of El Niño can also influence the $\mathrm{PNA}^{+}$by modulating high-frequency convectively tropical disturbances (Wang et al. 2013). Nevertheless, the detailed study of how the CP and EP types of El Niño affect the PNA via the changes in the Hadley cell and convectively tropical disturbances is beyond the scope of our present paper. Thus, in this paper we do not in detail examine the physical mechanism of how the El Niño type influences the $\mathrm{PNA}^{+}$through the changes in the Hadley cell and tropical convection. However, as noted below, the difference of the winter zonal winds associated with the Hadley cell between the CP and EP types of El 
displacement of enhanced Ferrell cell. Such an eastward displacement of the anticyclonic anomaly of the $\mathrm{PNA}^{+}$during the EP-type El Niño winter is also consistent with the modeling result of Yu et al. (2012b). The above results explain why the $\mathrm{PNA}^{+}$ cannot produce the North American WWCE dipole for an EP-type El Niño.

\section{Combined effect of the ENSO and PDO types on the PNA and North American} air temperatures

Here, we further examine the impact of the different phase of the PDO and its combination with the CP-type El Niño on the SAT anomaly over North America. We consider the winter of the PDO index with $\geqslant 0.5(\leqslant-0.5)$ STDs as a $\mathrm{PDO}^{+}\left(\mathrm{PDO}^{-}\right)$ winter for the normalized winter PDO index as shown in Fig. 12a. We show the composite DJF-mean SST anomaly fields in Figs. $12 \mathrm{~b}-\mathrm{c}$ for $\mathrm{PDO}^{+}$and $\mathrm{PDO}^{-}$, whereas the time-mean composite daily Z500 and SAT anomalies averaged from lag -5 to 5 days of $\mathrm{PNA}^{+}$events are shown in Figs. 12d-f. Clearly, the $\mathrm{PDO}^{+}\left(\mathrm{PDO}^{-}\right)$has a footprint of the El Niño (La Niña) signal over the equatorial Pacific (Figs. 12b-c) as noted in Wang et al. (2013). The investigation of their relationship is beyond the scope of our study, because the relationship between PDO and ENSO has been examined in detail in Wang et al. (2012a). It is noted that the $\mathrm{PNA}^{+}$resembling a midlatitude wave train in the timemean Z500 anomaly field can correspond to a WWCE dipole over North America for $\mathrm{PDO}^{+}$(Fig.12d), whose spatial shape is also consistent with the result of Kumar et al. (2013). The WWCE dipole is hardly seen for $\mathrm{PDO}^{-}$(Fig.12e), even though the $\mathrm{PNA}^{+}$is present. Although some of the PDO variability can come from the atmospheric surface wind forcing (Wang et al. 2012b), it does not imply that the $\mathrm{PNA}^{+}$with a timescale of 
10-20 days cannot be modulated by the phase of PDO. In contrast, the PDO and its combination with El Niño can modulate the sub-seasonal $\mathrm{PNA}^{+}$and associated subseasonal North American WWCE dipole.

While the CP-type El Niño favors the North American WWCE dipole via the generation of the $\mathrm{PNA}^{+}$, the PDO as a decadal signal of the Pacific SST can modulate the effect of the CP-type El Niño on the changes of the $\mathrm{PNA}^{+}$and associated North American SAT anomaly. Here, we will further explore this issue. A CP-type El Niño and $\mathrm{PDO}^{+}\left(\mathrm{PDO}^{-}\right)$combination is defined if the $\mathrm{CP}$ index has a value $\geqslant 0.5 \mathrm{STD}$ and the PDO index is positive above (negative below) zero. To understand the impact of the CP-type El Niño with the different phases of PDO on the North American WWCE dipole related to the $\mathrm{PNA}^{+}$, we first show the DJF-mean SST anomalies in Figs. 13a-c for the CP-type El Niño and $\mathrm{PDO}^{+}$combination and the CP-type El Niño and PDOcombination as well as their difference. Figures $13 \mathrm{~d}-\mathrm{f}$ show the time-mean composite daily Z500 and SAT anomalies averaged from lag -5 to 5 days of $\mathrm{PNA}^{+}$events for the two combinations and their difference. It is seen that the $\mathrm{PNA}^{+}$can produce a typical North American WWCE dipole (Fig. 13d) if the Pacific SST anomaly corresponds to the combination of a CP-type El Niño and a $\mathrm{PDO}^{+}$(Fig. 13a). But it is relatively weak under the Pacific SST anomaly condition with the combination of a CP-type El Niño and a $\mathrm{PDO}^{-}$(Fig. 13b). The temporal variation of $\mathrm{T}_{\mathrm{WE}}=\mathrm{T}_{\mathrm{W}}-\mathrm{T}_{\mathrm{E}}$ can indicate this point, if $\mathrm{T}_{\mathrm{W}}$ and $\mathrm{T}_{\mathrm{E}}$ are defined as the domain-averaged SAT anomaly over the west $\left(\mathrm{T}_{\mathrm{W}}: 40^{\circ} \mathrm{N}-\right.$ $\left.70^{\circ} \mathrm{N}, 130^{\circ} \mathrm{W}-100^{\circ} \mathrm{W}\right)$ and east $\left(\mathrm{T}_{\mathrm{E}}: 25-50^{\circ} \mathrm{N}, 95^{\circ} \mathrm{W}-65^{\circ} \mathrm{W}\right)$ parts of North America (Figure S4). Thus, the $\mathrm{PDO}^{+}\left(\mathrm{PDO}^{-}\right)$can enhance (reduce) the role of the CP-type $\mathrm{El}$ 
Niño in the North American WWCE dipole by strengthening (weakening) the warm anomalies over the west part of North America and cold anomalies over its east part.

\section{Conclusion and discussions}

A notable warm west/cold east (WWCE) zonal temperature dipole occurred over North America during 2013/14 and 2014/15 winters, which is characterized by an anticyclonic anomaly over the west part of North America and a negative height anomaly over the east part of North America. By inspecting the composite results of PNA events in 2013/14 and 2014/15 winters, it is found that although the positive PNA $\left(\mathrm{PNA}^{+}\right)$events occurred in the two winters, the effect of the $\mathrm{PNA}^{+}$is different between the two winters. Such a difference is likely related to the different background conditions. The most notable difference between the $2013 / 14$ and $2014 / 15$ winters is that the two winters correspond to different SST anomalies over Pacific. Thus, it is speculated that the $\mathrm{PNA}^{+}$could be significantly influenced by the winter SST anomalies in Pacific, even though it is an internal mode. This motivates us to examine under what oceanic condition the $\mathrm{PNA}^{+}$can lead to a typical WWCE dipole.

In order to establish the link of the $\mathrm{PNA}^{+}$change with the oceanic condition, it is useful to classify the North American SAT anomaly associated with the $\mathrm{PNA}^{+}$pattern using the K-means clustering method. By compositing daily Z500 anomalies associated with the six clustering regimes, one can know what types of $\mathrm{PNA}^{+}$anomalies correspond to what types of SAT patterns. It is noted that C3 corresponds to a typical North American WWCE dipole with a strong cold (warm) anomaly over the east (west) part of North America. While C4 corresponds to a WWCE dipole, the cold anomaly 
over the eastern North America is relatively weak. It is also found that while C3 and C4 have a significant correlation with the CP-type El Niño and $\mathrm{PDO}^{+}$, the SST anomaly over the pacific is relatively weak for $\mathrm{C} 4$. The $\mathrm{PNA}^{+}$associated with $\mathrm{C} 5$, which does not produce a WWCE dipole, is strongly related to the EP-type El Niño. This suggests that the type of the El Niño can influence the $\mathrm{PNA}^{+}$and associated North American SAT anomaly.

Furthermore, it is shown that while the CP- (EP-) type El Niño favors (suppresses) the North American WWCE dipole associated with the $\mathrm{PNA}^{+}$, the phase of PDO can modulate the role of CP-type El Niño in the North American WWCE dipole whose negative phase tends to suppress the WWCE dipole of the $\mathrm{PNA}^{+}$under the CP-type El Niño. In addition, we further examine why the CP-type or EP-type El Niño can influence the $\mathrm{PNA}^{+}$by calculating the winter zonal winds and mass stream function (MSF) associated with the type of El Niño. It is revealed that the type of El Niño can influence the position of the anticyclonic anomaly of the $\mathrm{PNA}^{+}$through changing Hadley and Ferrell cells and associated zonal winds over North Pacific. For the EP-type El Niño, the zonal winds over North Pacific midlatitudes are intensified to cause the eastward shift of the $\mathrm{PNA}^{+}$and make its anticyclonic anomaly appear in the whole North America due to intensified Hadley cell and Ferrell cell. Such a $\mathrm{PNA}^{+}$does not produce a North American WWCE dipole. The reversed is seen for a CP-type El Niño. Under a CP-type El Niño condition the Hadley cell is expanded northward, which corresponds to reduced midlatitude zonal winds over North Pacific favoring the westward shift of the $\mathrm{PNA}^{+}$and the appearance of the anticyclonic (cyclonic) anomaly 
of the $\mathrm{PNA}^{+}$in the North American west (east). Such a $\mathrm{PNA}^{+}$shift can generate an

467 intense North American WWCE dipole.

468 However, it must be pointed out that in this paper we do not examine the role of 469 combined PNA and NAO in generating the North American WWCE dipole. In fact, 470 although the $\mathrm{PNA}^{+}\left(\mathrm{PNA}^{-}\right)$often accompanies the $\mathrm{NAO}^{-}\left(\mathrm{NAO}^{+}\right)$, the relationship 471 between the PNA and NAO is not stable (Pinto et al. 2011). Thus, it is also useful to 472 classify the role of the $\mathrm{PNA}^{+}$events associated with the different phases of NAO in the 473 North American WWCE dipole in our future work. This problem deserves a further 474 study.

\section{Acknowledgements}

478 This research was supported by the National Natural Science Foundation of China 479 (Grant numbers: 41790473), Chinese Academy of Sciences Strategic Priority Research 480 Program (Grant XDA19070403) and the National key research and development 481 program of China (2016YFA0601802). 
Baxter, S., S. Nigam (2015), Key Role of the North Pacific Oscillation-West P acific Pattern in Generating the Extreme 2013/14 North American Winte r, Journal of Climate, 28(20), http://dx.doi.org/10.1175/jcli-d-14-00726.1.

Champagne, O., B. Pohl, S. McKenzie, J. F. Buoncristiani, E. Bernard, D. Joly, F. Tolle (2019), Atmospheric circulation modulates the spatial variability of temperature in the Atlantic-Arctic region, International Journal of Cli matology, 39(8), 3619-3638, http://dx.doi.org/10.1002/joc.6044.

Chen, X., D. Luo (2017), Arctic sea ice decline and continental cold anomalie s: Upstream and downstream effects of Greenland blocking, Geophysical Research Letters, 44(7), 3411-3419, http://dx.doi.org/10.1002/2016g107238 7.

Chen, X., D. Luo (2019), Winter Midlatitude Cold Anomalies Linked to North Atlantic Sea Ice and SST Anomalies: The Pivotal Role of the Potential Vorticity Gradient, Journal of Climate, 32(13), 3957-3981, http://dx.doi.o $\underline{\mathrm{rg} / 10.1175 / \text { jcli-d-18-0504.1. }}$.

Chien, Y. T., S. Y. S. Wang, Y. Chikamoto, S. L. Voelker, J. D. D. Meyer, an d J. H. Yoon (2019), North American Winter Dipole: Observed and Sim ulated Changes in Circulations, Atmosphere, 10(12), 15, http://dx.doi.org/ 10.3390/atmos10120793.

Ding, R., J. Li, Y.-h. Tseng, C. Sun, and Y. Guo (2015), The Victoria mode i $\mathrm{n}$ the North Pacific linking extratropical sea level pressure variations to 
ENSO, Journal of Geophysical Research: Atmospheres, 120(1), 27-45, ht tps://doi.org/10.1002/2014JD022221.

508 Feldstein, S. B. (2002), Fundamental mechanisms of the growth and decay of $t$ he PNA teleconnection pattern, Quarterly Journal of the Royal Meteorol ogical Society, 128(581), 775-796, https://doi.org/10.1256/00359000216436 

$\underline{02 / 2015 \mathrm{~g} 1063083 .}$

Hoskins, B. J., D. J. Karoly (1981), The steady linear response of a spherical atmosphere to thermal and orographic forcing, Journal of the Atmospheri c Sciences, 38(6), 1179-1196, http://dx.doi.org/10.1175/1520-0469(1981)03

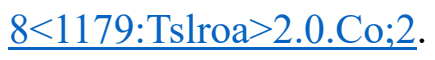

Kalnay, E., et al. (1996), The NCEP/NCAR 40-year reanalysis project, Bulletin of the American Meteorological Society, 77(3), 437-471, http://dx.doi.org/ 10.1175/1520-0477(1996)077<0437:Tnyrp >2.0.Co;2.

Kao, H.-Y., J.-Y. Yu (2009), Contrasting Eastern-Pacific and Central-Pacific Typ es of ENSO, Journal of Climate, 22(3), 615-632, http://dx.doi.org/10.117 5/2008jcli2309.1.

Kug, J.-S., F.-F. Jin, S.-I. An (2009), Two Types of El Niño Events: Cold Ton gue El Niño and Warm Pool El Niño, Journal of Climate, 22(6), 14991515, http://dx.doi.org/10.1175/2008jcli2624.1.

Kumar, A., H. Wang, W. Wang, Y. Xue, and Z.-Z. Hu (2013), Does Knowing the Oceanic PDO Phase Help Predict the Atmospheric Anomalies in Subsequent Months?: Journal of Climate, 26, 1268-1285. http://dx.doi.org/10.1175/JCLI-D$\underline{12-00057.1 .}$.

Lee, M.-Y., C.-C. Hong, H.-H. Hsu (2015), Compounding effects of warm sea surface temperature and reduced sea ice on the extreme circulation over the extratropical North Pacific and North America during the 2013-2014 

oi.org/10.1002/2014g1062956.

Lee, T., M. J. McPhaden (2010), Increasing intensity of El Niño in the central -equatorial Pacific, Geophysical Research Letters, 37, http://dx.doi.org/10. $\underline{1029 / 2010 g 1044007 .}$

Luo, B., D. Luo, A. Dai, I. Simmonds, L. Wu (2020), Combined Influences o $\mathrm{n}$ North American Winter Air Temperature Variability from North Pacifi c Blocking and the North Atlantic Oscillation: Subseasonal and Interann ual Time Scales, Journal of Climate, 33(16), 7101-7123, http://dx.doi.org/ 10.1175/jcli-d-19-0327.1.

Luo, D., Y. Ge, W. Zhang, A. Dai (2020), A Unified Nonlinear Multiscale Inte raction Model of Pacific-North American Teleconnection Patterns, Journa 1 of the Atmospheric Sciences, 77(4), 1387-1414, http://dx.doi.org/10.117 5/jas-d-19-0312.1.

Michelangeli, P. A., R. Vautard, and B. Legras (1995), Weather regimes - recur rence and quasi stationarity, Journal of the Atmospheric Sciences, 52(8), 1237-1256, http://dx.doi.org/10.1175/1520-0469(1995)052<1237:Wrraqs $>2.0$. $\underline{\mathrm{Co} ; 2}$.

Peng, P., A. Kumar, M. Chen, Z.-Z. Hu, B. Jha (2019), Was the North Americ an extreme climate in winter 2013/14 a SST forced response?, Climate Dynamics, 52(5-6), 3099-3110, http://dx.doi.org/10.1007/s00382-018-4314$\underline{0}$. 
Peng, P., A. Kumar, Z.-Z. Hu (2018), What drove the Pacific and North Amer ica climate anomalies in winter 2014/15?, Climate Dynamics, 51(7-8), 2 667-2679, http://dx.doi.org/10.1007/s00382-017-4035-9.

Peng, P., A. Kumar, B. Jha (2014), Climate mean, variability and dominant pat terns of the Northern Hemisphere wintertime mean atmospheric circulatio $\mathrm{n}$ in the NCEP CFSv2, Climate Dynamics, 42(9-10), 2783-2799, http://d x.doi.org/10.1007/s00382-014-2116-6.

Pinto, J. G., M. Reyers, U. Ulbrich (2011), The variable link between PNA an d NAO in observations and in multi-century CGCM simulations, Climat e Dynamics, 36(1-2), 337-354, http://dx.doi.org/10.1007/s00382-010-0770$\underline{x}$.

Rayner, N. A., D. E. Parker, E. B. Horton, C. K. Folland, L. V. Alexander, D. P. Rowell, E. C. Kent, A. Kaplan (2003), Global analyses of sea surfa ce temperature, sea ice, and night marine air temperature since the late nineteenth century, Journal of Geophysical Research-Atmospheres, 108(D 14), http://dx.doi.org/10.1029/2002jd002670.

Schulte, J. A., S. Lee (2017), Strengthening North Pacific Influences on United States Temperature Variability, Scientific Reports, 7, http://dx.doi.org/10. $\underline{1038 / \mathrm{s} 41598-017-00175-\mathrm{y}}$.

Seager, R., N. Henderson (2016), On the Role of Tropical Ocean Forcing of $t$ he Persistent North American West Coast Ridge of Winter 2013/14, Jour nal of Climate, 29(22), 8027-8049, http://dx.doi.org/10.1175/jcli-d-16-0145. 
Singh, D., D. L. Swain, J. S. Mankin, D. E. Horton, L. N. Thomas, B. Rajara tnam, N. S. Diffenbaugh (2016), Recent amplification of the North Ame rican winter temperature dipole, Journal of Geophysical Research-Atmosp heres, 121(17), 9911-9928, http://dx.doi.org/10.1002/2016jd025116.

Straus, D. M., J. Shukla (2002), Does ENSO force the PNA? Journal of Clima te, 15(17), 2340-2358, http://dx.doi.org/10.1175/1520-0442(2002)015<2340: $\underline{\operatorname{Deftp}>2.0 . \mathrm{Co}_{2} ; .}$

Wang, H., A. Kumar, W. Wang, Y. Xue (2012a), Influence of ENSO on Pacific decadal variability: An analysis based on the NCEP climate forecast system: J. Climate, 25, 6136-6151. http://dx.doi.org/10.1175/JCLI-D-11-00573.1.

Wang, H., A. Kumar, W. Wang, and Y. Xue (2012b), Seasonality of the Pacific Decadal Oscillation: J. Climate, 25, 25-38. http://dx.doi.org/10.1175/2011JCLI4092.1.

Wang, H., Y. Pan, A. Kumar and W. Wang (2013), Modulation of convectively coupled Kelvin wave activity in the tropical Pacific by ENSO. Acta Meteor. Sinica, 27(3), 295-307, doi: 10.10, 07/s13351-013-0306-5.

Wang, S.-Y. S., W.-R. Huang, J.-H. Yoon (2015), The North American winter ' dipole' and extremes activity: a CMIP5 assessment, Atmospheric Science Letters, 16(3), 338-345, http://dx.doi.org/10.1002/as12.565.

Wang, S.-Y. S., L. Hipps, R. R. Gillies, J.-H. Yoon (2014), Probable causes of the abnormal ridge accompanying the 2013-2014 California drought: EN SO precursor and anthropogenic warming footprint, Geophysical Researc 
617

Wang, S.-Y. S., J.-H. Yoon, E. Becker, R. Gillies (2017), California from drou ght to deluge, Nature Climate Change, 7(7), 465-468, http://dx.doi.org/10. 1038/nclimate3330.

Xie, J., M. Zhang (2017), Role of internal atmospheric variability in the 2015 extreme winter climate over the North American continent, Geophysical Research Letters, 44(5), 2464-2471, http://dx.doi.org/10.1002/2017g107277 2 .

Yu, B., H. Lin (2018), Modification of the wintertime Pacific-North American pattern related North American climate anomalies by the Asian-Bering-N orth American teleconnection, Climate Dynamics, 53(1-2), 313-328, http:/ /dx.doi.org/10.1007/s00382-018-4586-4.

Yu, B., H. Lin, Z. W. Wu, W. J. Merryfield (2016), Relationship between Nort $\mathrm{h}$ American winter temperature and large-scale atmospheric circulation a nomalies and its decadal variation, Environmental Research Letters, 11 (7), http://dx.doi.org/10.1088/1748-9326/11/7/074001.

Yu, B., H. Lin, Z. W. Wu, W. J. Merryfield (2017), The Asian-Bering-North A merican teleconnection: seasonality, maintenance, and climate impact on North America, Climate Dynamics, 50(5-6), 2023-2038, http://dx.doi.org/1 $\underline{0.1007 / \mathrm{s} 00382-017-3734-6 .}$.

Yu, B., X. Zhang (2015), A physical analysis of the severe 2013/2014 cold wi nter in North America, Journal of Geophysical Research-Atmospheres, 1 
639 Yu, J.-Y., M.-M. Lu, S. T. Kim (2012a), A change in the relationship between tropical central Pacific SST variability and the extratropical atmosphere around 1990, Environmental Research Letters, 7(3), http://dx.doi.org/10.10 $\underline{88 / 1748-9326 / 7 / 3 / 034025 .}$

643 Yu, J.-Y., Y. Zou, S. T. Kim, T. Lee (2012b), The changing impact of El Niñ 
648 Table 1. Correlation coefficients between the WWCE index (Fig 4b) and the six 649 clustering regimes: C1, C2, C3, C4, C5, C6 (Fig. 7). The two asteriks represents the 650 coefficient with a $95 \%$ confidence level.

651

\begin{tabular}{|l|l|l|l|l|l|l|}
\hline & C1 & C2 & C3 & C4 & C5 & C6 \\
\hline WWCE & $\mathbf{- 0 . 2 7 ^ { * * }}$ & 0.03 & $\mathbf{0 . 4 1}$ & $\mathbf{0 . 3 4}^{* *}$ & -0.14 & 0.06 \\
\hline
\end{tabular}

652

653 Table 2. Correlation coefficients of $\mathrm{PNA}^{+}, \mathrm{PNA}^{-}, \mathrm{C} 1, \mathrm{C} 2, \mathrm{C} 3, \mathrm{C} 4, \mathrm{C} 5$ and $\mathrm{C} 6$ regime

654 events with the Niño1+2, Niño4, CP-type El Niño, EP-type El Niño and PDO indices.

655 The one asterik (two asteriks) represents the coefficient with the 90\% (95\%) confidence 656 level.

\begin{tabular}{|c|c|c|c|c|c|}
\hline & Niño1+2 & Niño4 & CP index & EP index & PDO \\
\hline PNA $^{+}$ & $\mathbf{0 . 3 4}^{* *}$ & $\mathbf{0 . 2 6}^{* *}$ & 0.11 & $\mathbf{0 . 2 9}^{* *}$ & $\mathbf{0 . 3 1}^{* *}$ \\
\hline PNA $^{-}$ & $\mathbf{- 0 . 2 6}^{* *}$ & $\mathbf{- 0 . 2 3}^{*}$ & -0.16 & $\mathbf{- 0 . 2 3}^{*}$ & $\mathbf{- 0 . 4 3}^{* *}$ \\
\hline C1 & 0.17 & -0.06 & -0.18 & $\mathbf{0 . 2 9}^{* *}$ & -0.11 \\
\hline C2 & -0.06 & -0.15 & -0.16 & 0.06 & -0.16 \\
\hline C3 & 0.14 & $\mathbf{0 . 2 8}^{* *}$ & $\mathbf{0 . 2 2}^{*}$ & -0.13 & $\mathbf{0 . 2 9}^{* *}$ \\
\hline C4 & -0.02 & 0.16 & $\mathbf{0 . 2 2}^{*}$ & -0.11 & $\mathbf{0 . 2 2}^{*}$ \\
\hline C5 & $\mathbf{0 . 3 9}^{* *}$ & $\mathbf{0 . 2 2}^{*}$ & 0.03 & $\mathbf{0 . 3 7}^{* *}$ & $\mathbf{0 . 2 1}^{*}$ \\
\hline C6 & 0.02 & 0.11 & 0.17 & 0.01 & $\mathbf{0 . 2 5}^{*}$ \\
\hline C3+C4 & 0.06 & $\mathbf{0 . 3 0}^{* *}$ & $\mathbf{0 . 3 1}$ & -0.16 & $\mathbf{0 . 3 5}^{* *}$ \\
\hline
\end{tabular}


Z500 \& SAT anomaly (2013/14)

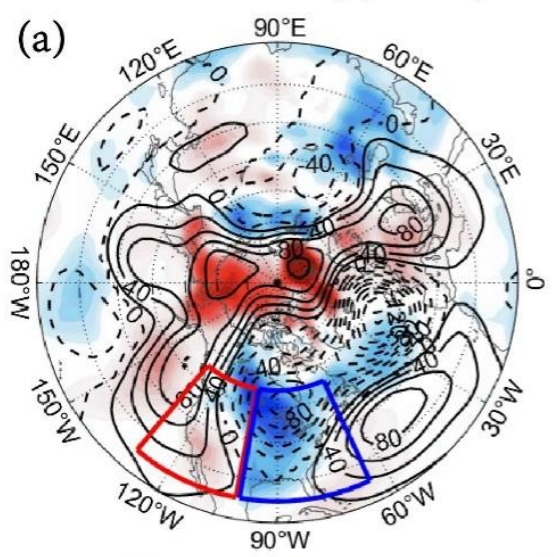

Z500 \& SAT anomaly (2014/15)

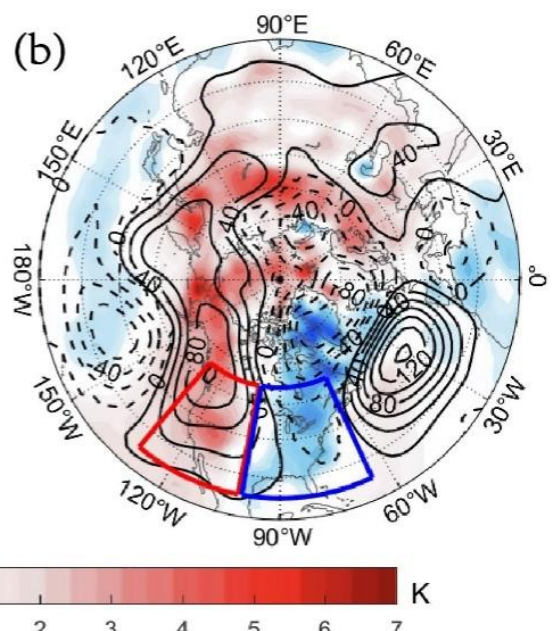

(d)

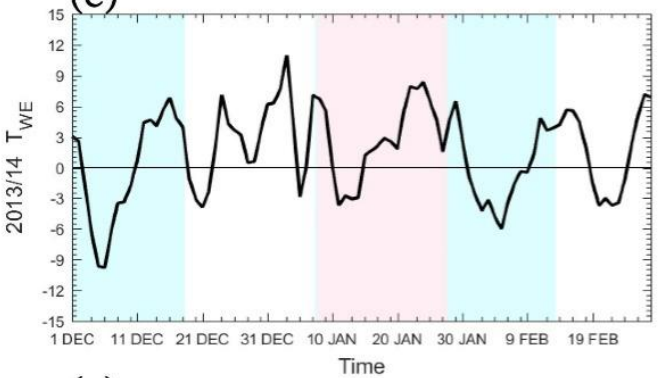

(e)

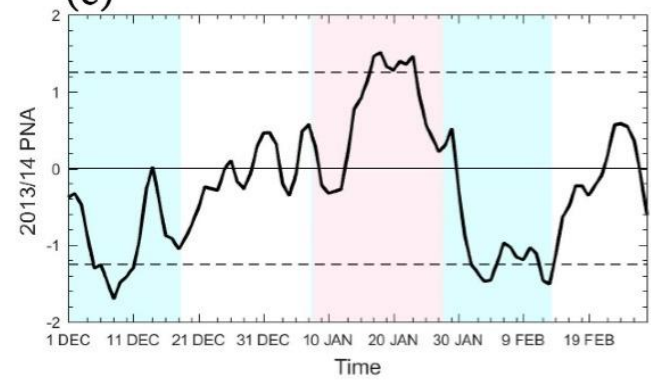

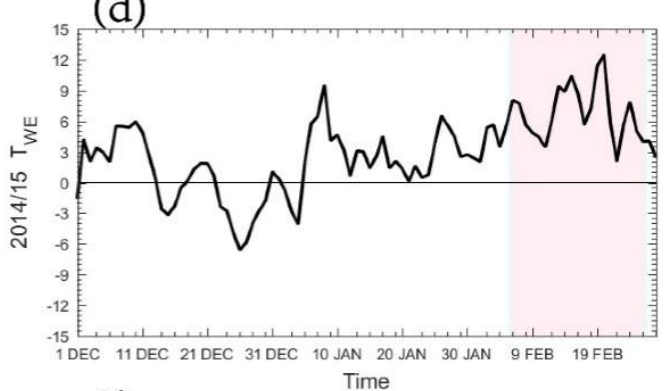

(f)

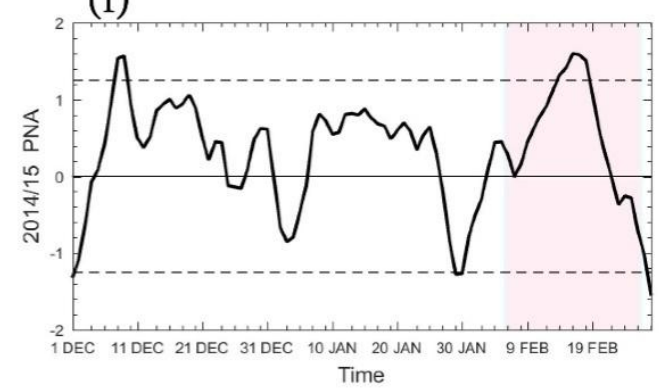

658

Figure 1. DJF-mean fields of Z500 (contours, contour interval (CI) is 20gpm) and SAT (color shading with the unit of K) anomalies in the (a) 2013/14 and (b) 2014/15 winters. (c-f) Temporal evolution of daily $\mathrm{T}_{\mathrm{WE}}=\mathrm{T}_{\mathrm{W}}-\mathrm{T}_{\mathrm{E}}$ and the PNA index for the (c, e) 2013/14 and $(\mathrm{d}, \mathrm{f})$ 2014/15 winters, where $\mathrm{T}_{\mathrm{W}}$ and $\mathrm{T}_{\mathrm{E}}$ represent domain-averaged SAT anomalies over the west $\left(25^{\circ} \mathrm{N}-55^{\circ} \mathrm{N}\right.$ and $130^{\circ} \mathrm{W}-100^{\circ} \mathrm{W}$, red box $)$ and east $\left(25^{\circ} \mathrm{N}-55^{\circ} \mathrm{N}, 100^{\circ} \mathrm{W}-\right.$ $65^{\circ} \mathrm{W}$, blue box) regions of North America, respectively. 


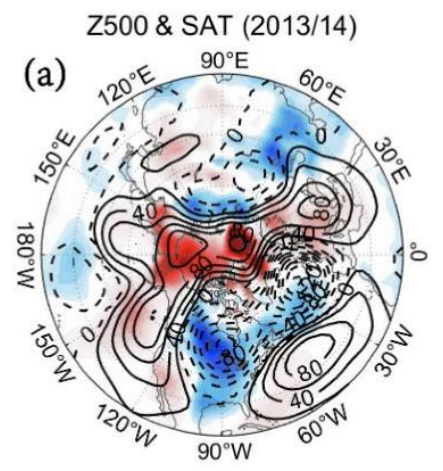

Z500 \& SAT (2013/14 without PNA)

(b)
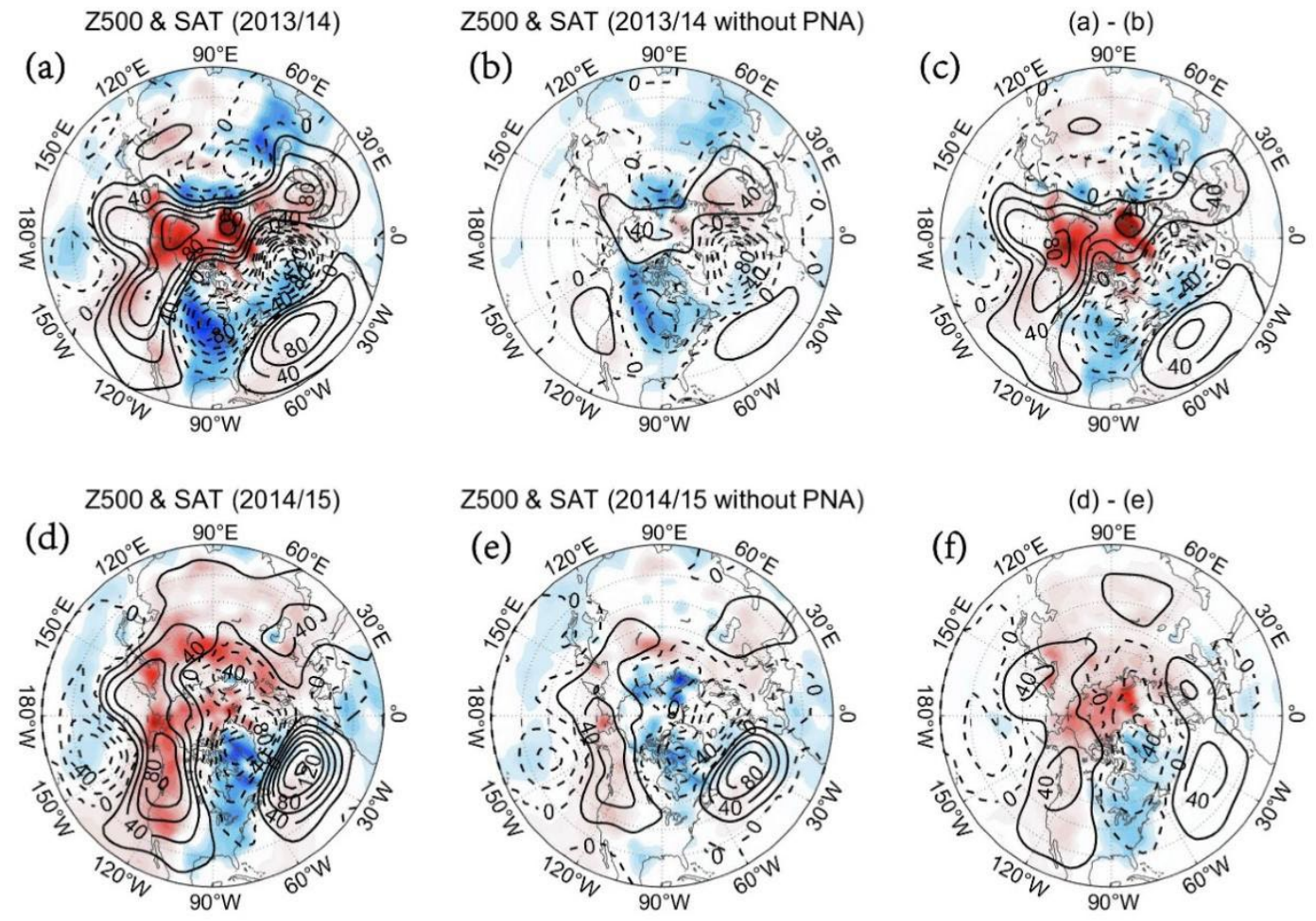

Z500 \& SAT (2014/15 without PNA)

(e)
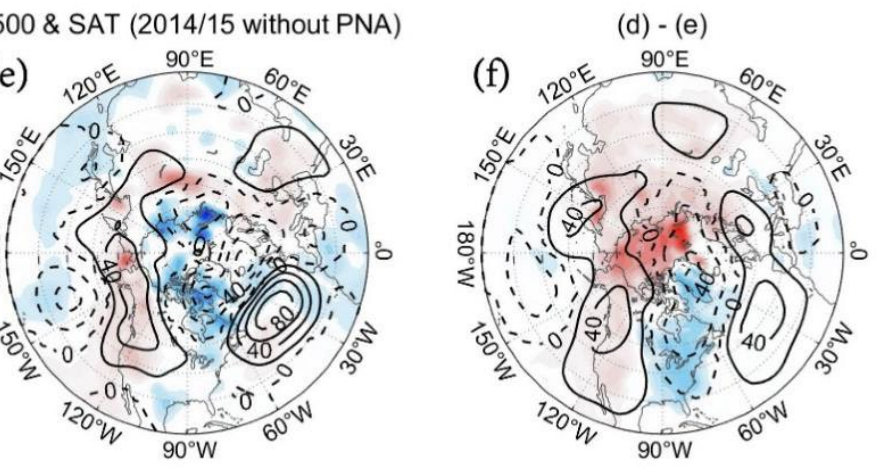

666

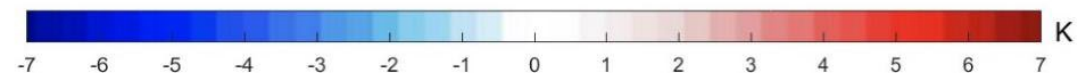

Figure 2. DJF-mean fields of Z500 (contours, $\mathrm{CI}=20 \mathrm{gpm}$ ) and SAT (color shading and

668 the unit is K) anomalies in the (a) 2013/14 and (d) 2014/15 winters. The time-mean

669 Z500 and SAT anomalies for the PNA events excluded (all the days from lag -10 and

67010 days of PNA events are removed) for the (b) 2013/2014 and (e) 2014/2015 winters. 

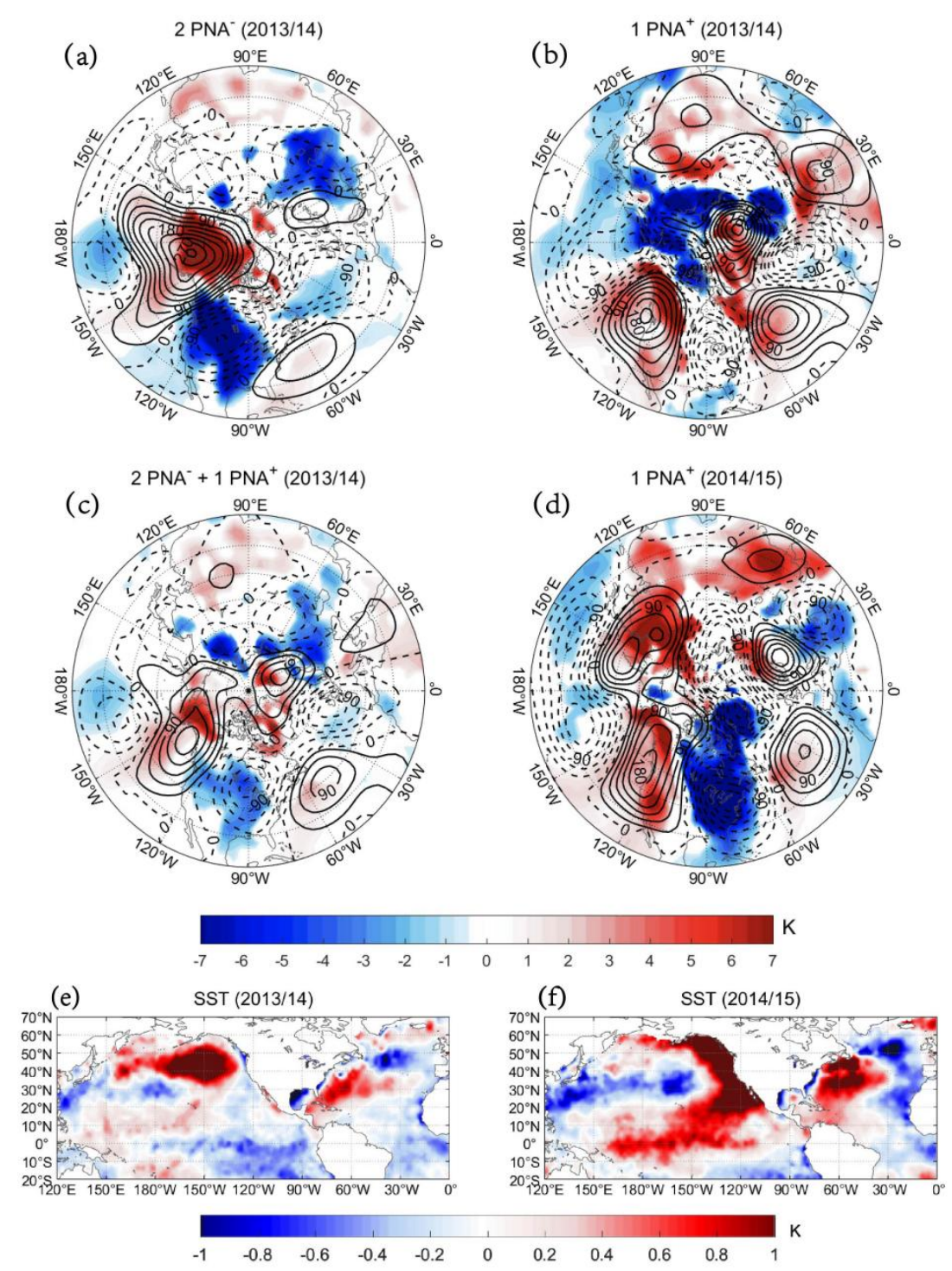

673 Figure 3. Time-mean fields of composite daily Z500 (contours, CI=30gpm) and SAT

674 (color shading) anomalies averaged from lag -5 to 5 days (lag 0 denotes the peak day 675 of the PNA) for (a) $\mathrm{PNA}^{-}$, (b) $\mathrm{PNA}^{+}$and (c) combined $\mathrm{PNA}^{-}$and $\mathrm{PNA}^{+}$events in the 676 2013/14 winter and (d) PNA $^{+}$events in the 2014/15 winter. (e, f) DJF-mean SST 677 anomalies for the (e) 2013/14 and (f) 2014/15 winters. In panels a-d, the region of the 678 SAT anomaly (color shading) deviated from the DJF-mean field during 1950-2018 679 winters with the $95 \%$ confidence level based on a two-sided Student's t-test is only 680 plotted. 

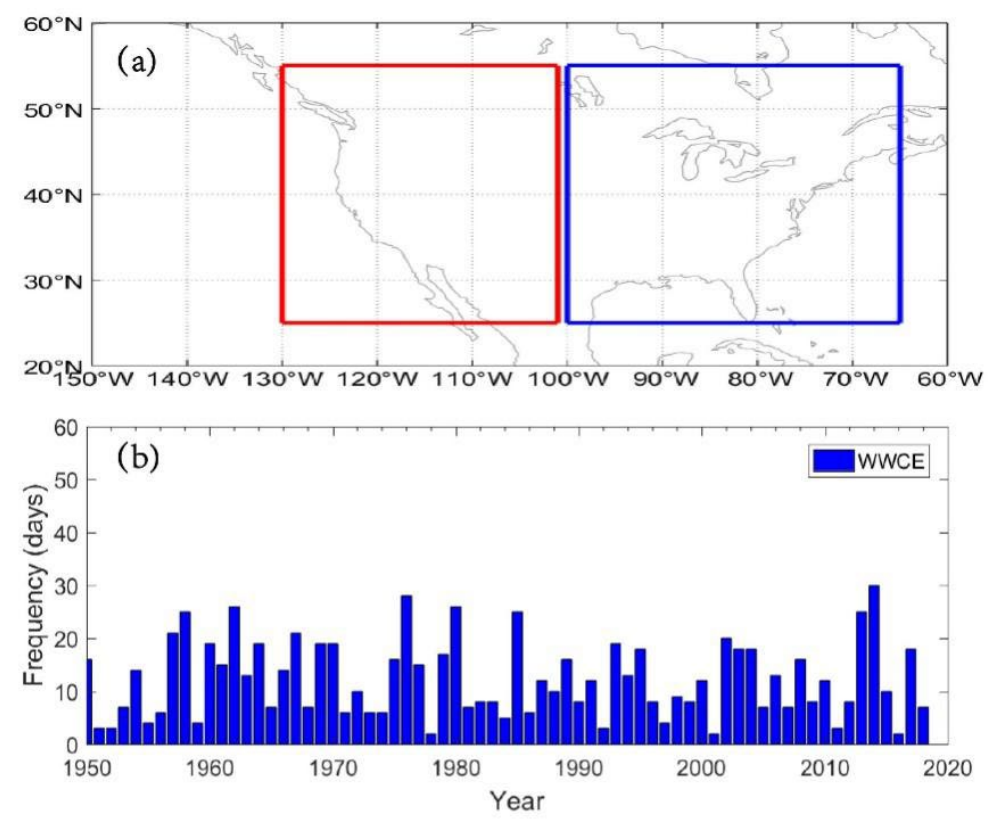

(c)

681

682 Figure 4. (a) The west (red box: $25^{\circ} \mathrm{N}-55^{\circ} \mathrm{N}, 130^{\circ} \mathrm{W}-100^{\circ} \mathrm{W}$ ) and east (blue box: $25^{\circ} \mathrm{N}-$ $55^{\circ} \mathrm{N}, 100^{\circ} \mathrm{W}-65^{\circ} \mathrm{W}$ ) regions of the North America. (b) Time series of the winter frequency (the number of total days) of daily WWCE events and (c) composite daily Z500 (contours, $\mathrm{CI}=20 \mathrm{gpm}$ ) and SAT (color shading and unit: K) anomaly fields for all days of North American WWCE dipole events during 1950-2018 winters, and the region of the SAT anomaly (color shading) with the $95 \%$ confidence level based on a two-sided Student's t-test is plotted. 

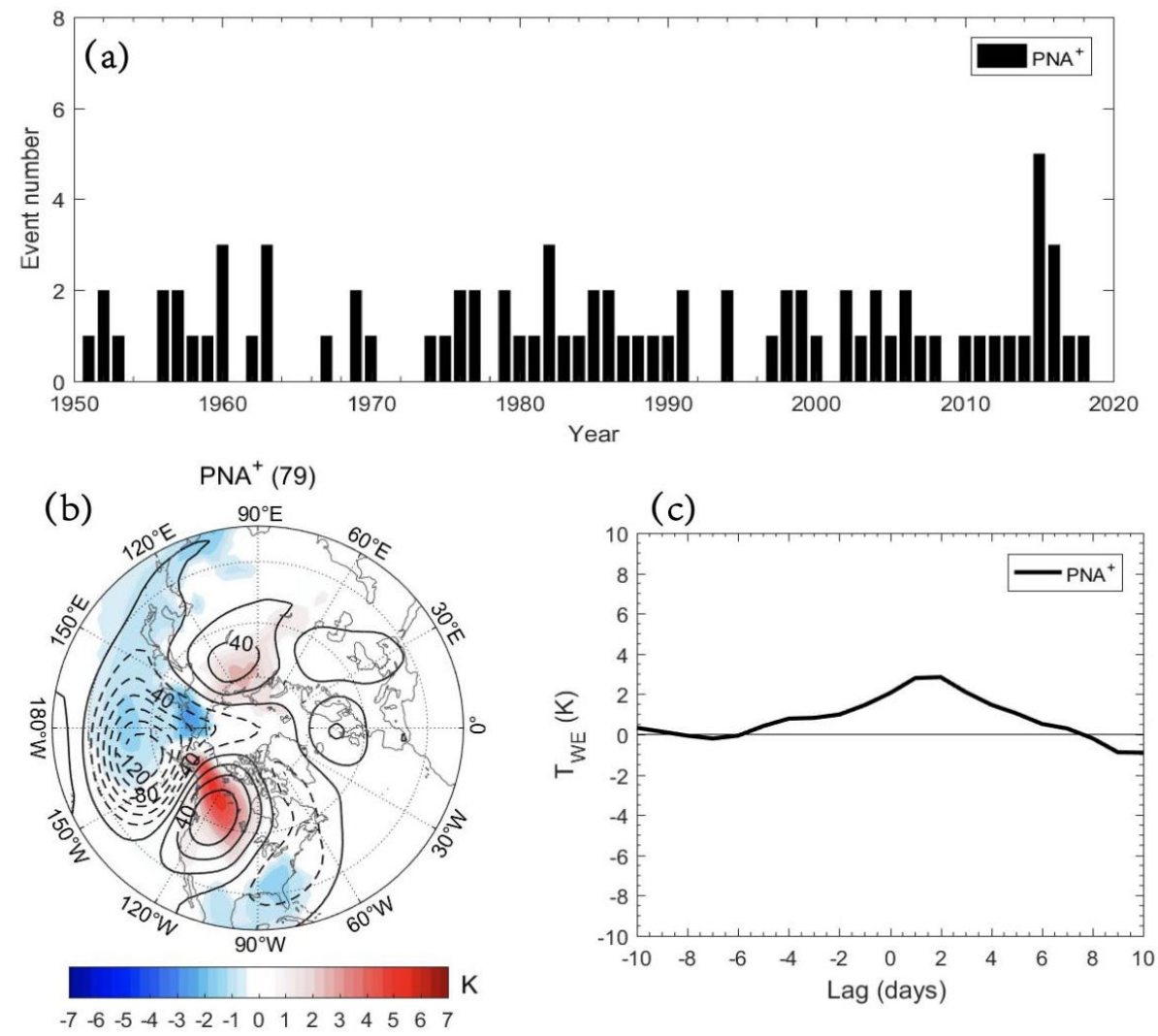

691 Figure 5. (a) Time series of the event number of $\mathrm{PNA}^{+-}$events in winter during 19502018. (b) Time-mean fields of composite daily Z500 (contours, CI=20 gpm) and SAT 693 (color shading in the unit of $\mathrm{K}$ ) anomalies averaged from lag-5 to 5 days of (b) $\mathrm{PNA}^{+}$ 694 events, where the region of the SAT anomaly (color shading) with the $95 \%$ confidence 695 level based on a two-sided Student's t-test is plotted. (c) Temporal variations of 696 composite daily TwE index during the PNA life cycle (from lag-10 to 10 days). 
C1 (13 events 16.5\%)

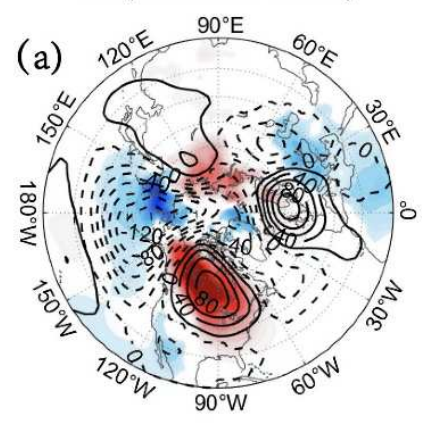

C4 (19 events $24.0 \%$ )

(d)
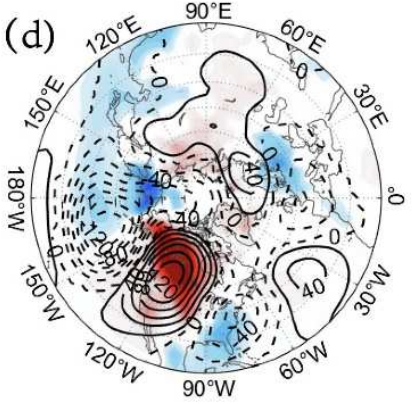

C2 (15 events $19.0 \%)$

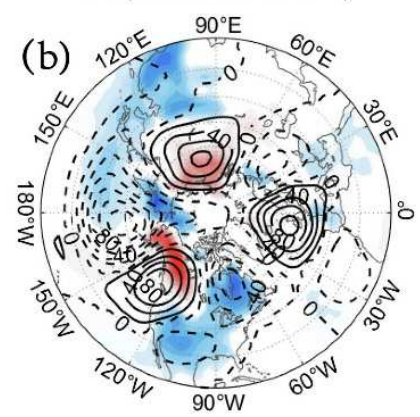

C5 (16 events 20.2\%)
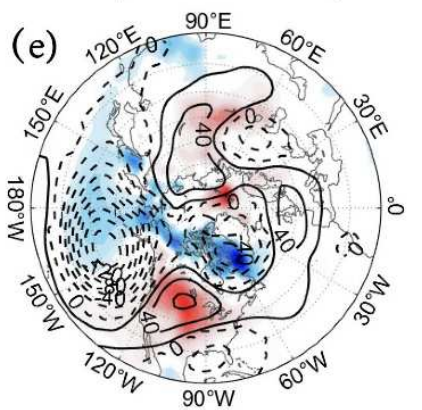

C3 (9 events $11.4 \%$ )

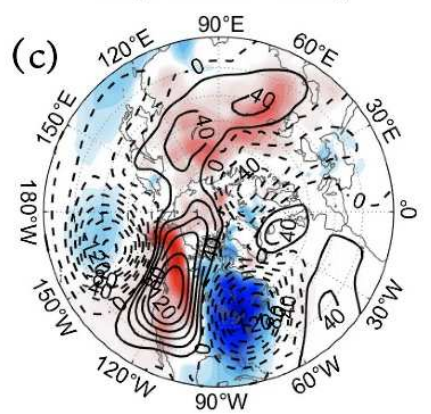

C6 (7 events $8.9 \%$ )
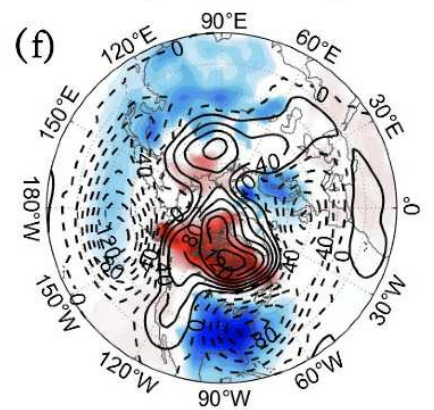

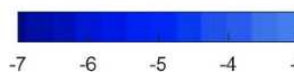

Figure 6. Time-mean fields of composite daily Z500 (contours, CI=20gpm) and SAT

SAT anomaly (color shading) with the $95 \%$ confidence level based on a two-sided 
(a)

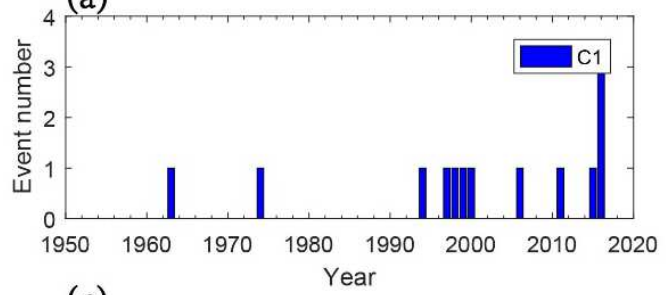

(c)

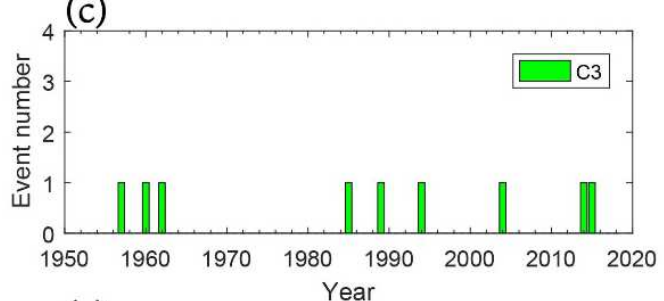

(e)

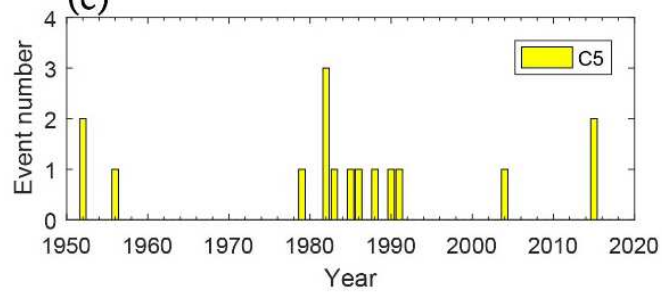

(b)

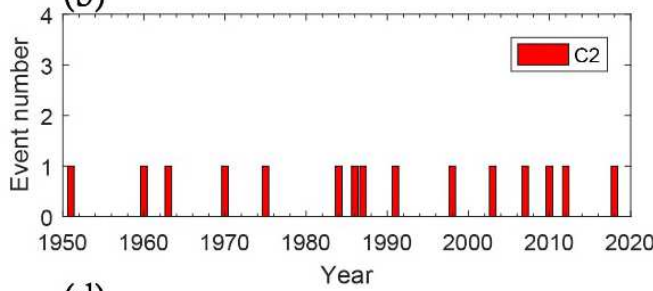

${ }_{4}(\mathrm{~d})$
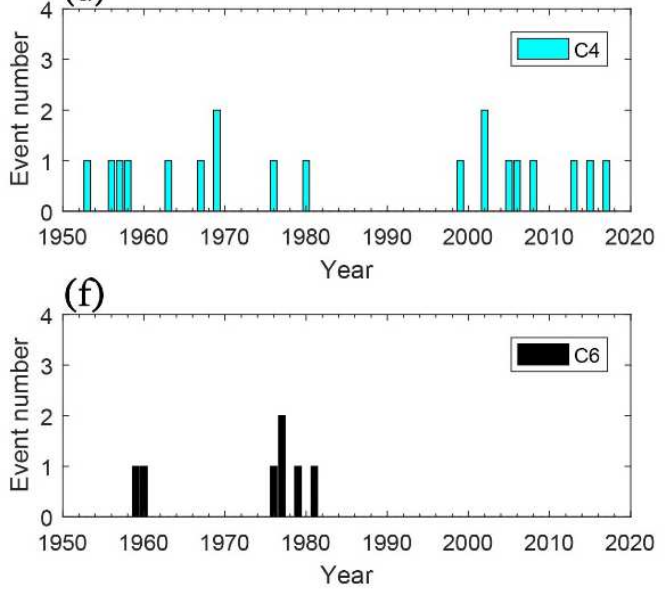

Figure 7. Time series of the event number of $\mathrm{PNA}^{+}$events for six clustering regimes:

(a) C1, (b) C2, (c) C3, (d) C4, (e) C5 and (f) C6 during 1950-2018 as shown in Fig. 6. 

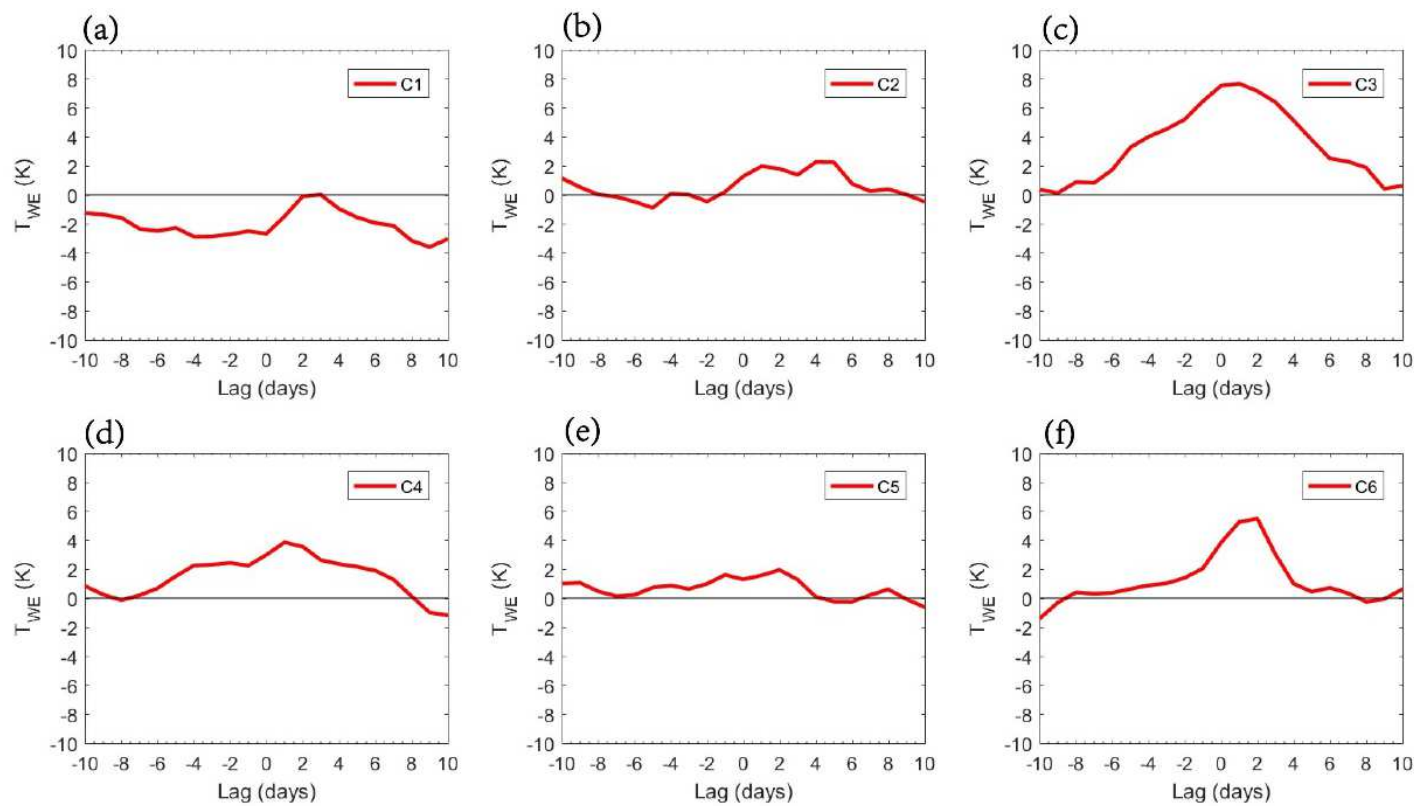

Figure 8. Temporal variations of composite daily $T_{W E}=T_{W}-T_{E}$ of the $\mathrm{PNA}^{+}$events

715 during the PNA life cycle (from lag-10 to 10 days) for the six clustering regimes: (a) averaged SAT anomalies over the west $\left(25^{\circ} \mathrm{N}-55^{\circ} \mathrm{N}, 130^{\circ} \mathrm{W}-100^{\circ} \mathrm{W}\right)$ and east $\left(25^{\circ} \mathrm{N}-\right.$ $55^{\circ} \mathrm{N}, 100^{\circ} \mathrm{W}-65^{\circ} \mathrm{W}$ ) regions of North America, respectively. 

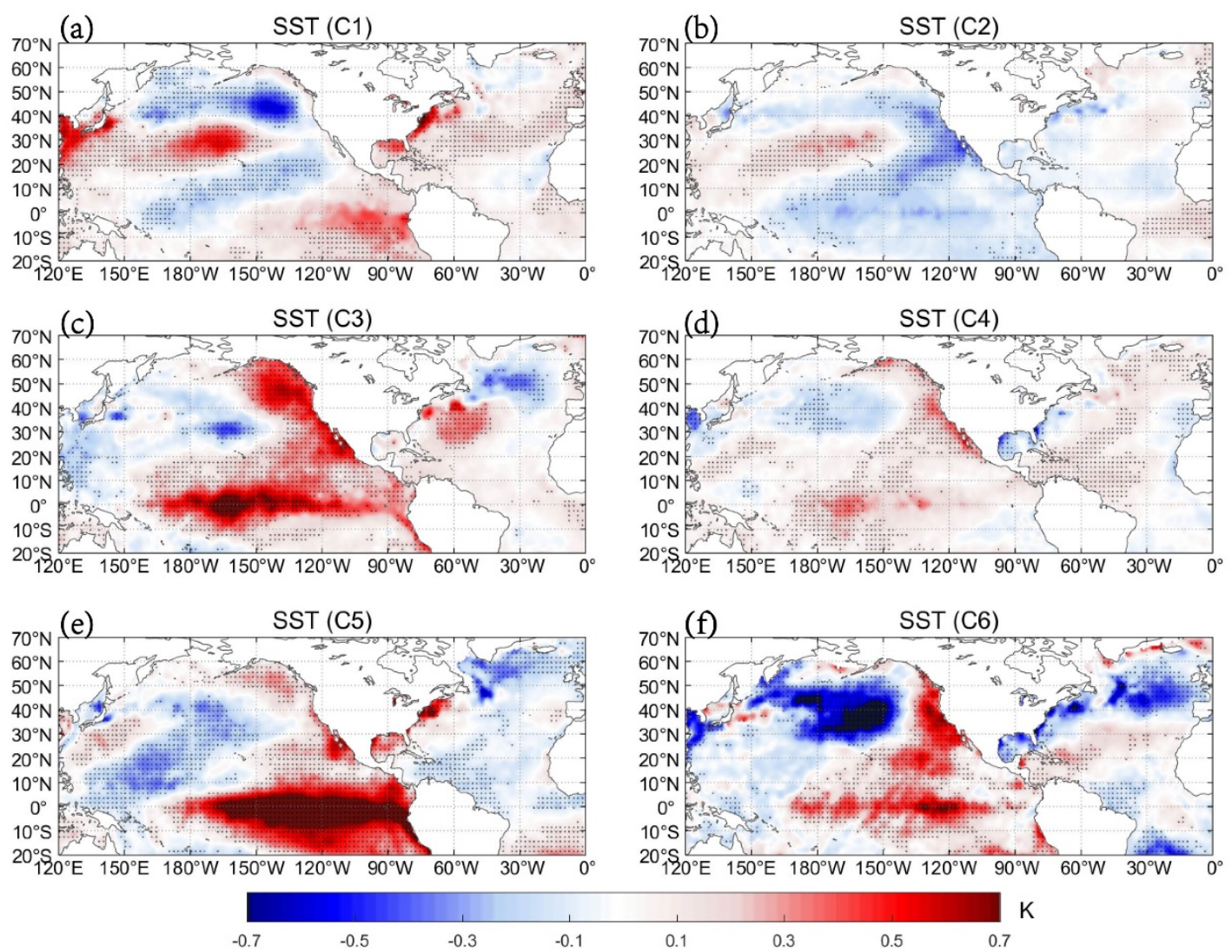

720 Figure 9. Composite DJF-mean SST anomalies (color shading and unit: K) for six

721 clustering regimes: (a) C1, (b) C2, (c) C3, (d) C4, (e) C5 and (f) C6 during 1950-2018

722 in Fig. 6. The dot represents the SST anomaly region above the 95\% confidence level

723 based on a two-sided Student's t-test. 

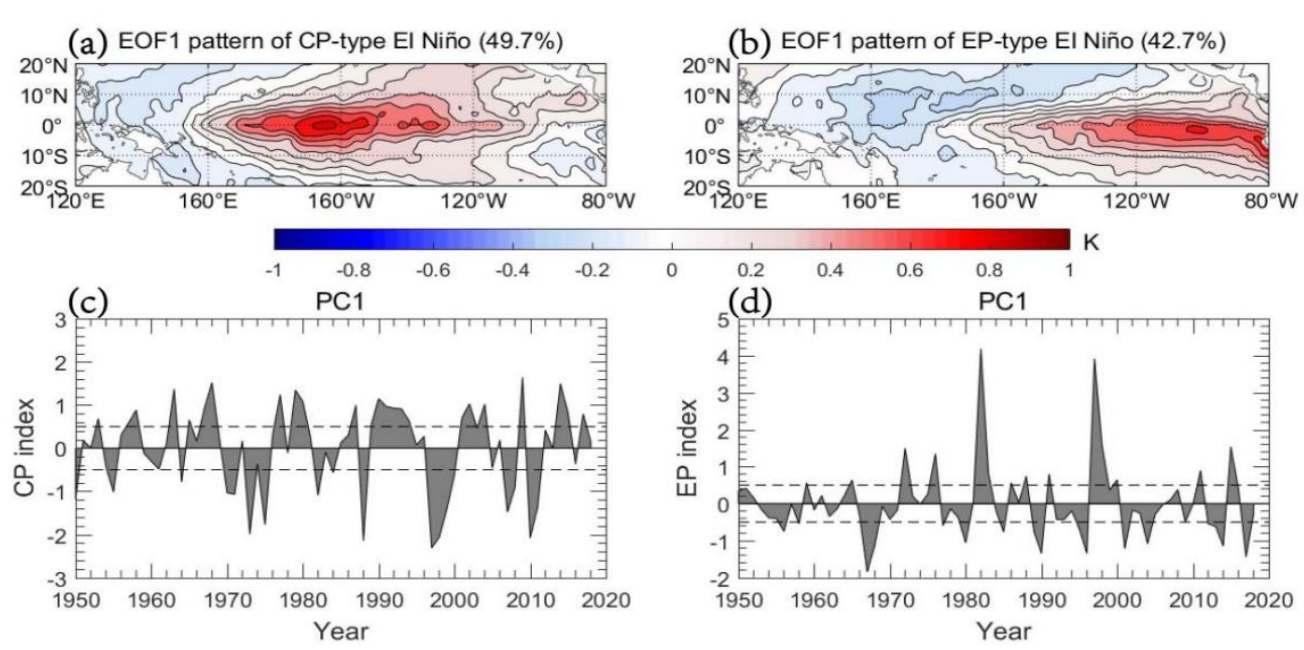

Z500 \& SAT (26 events in 23 CP-type)
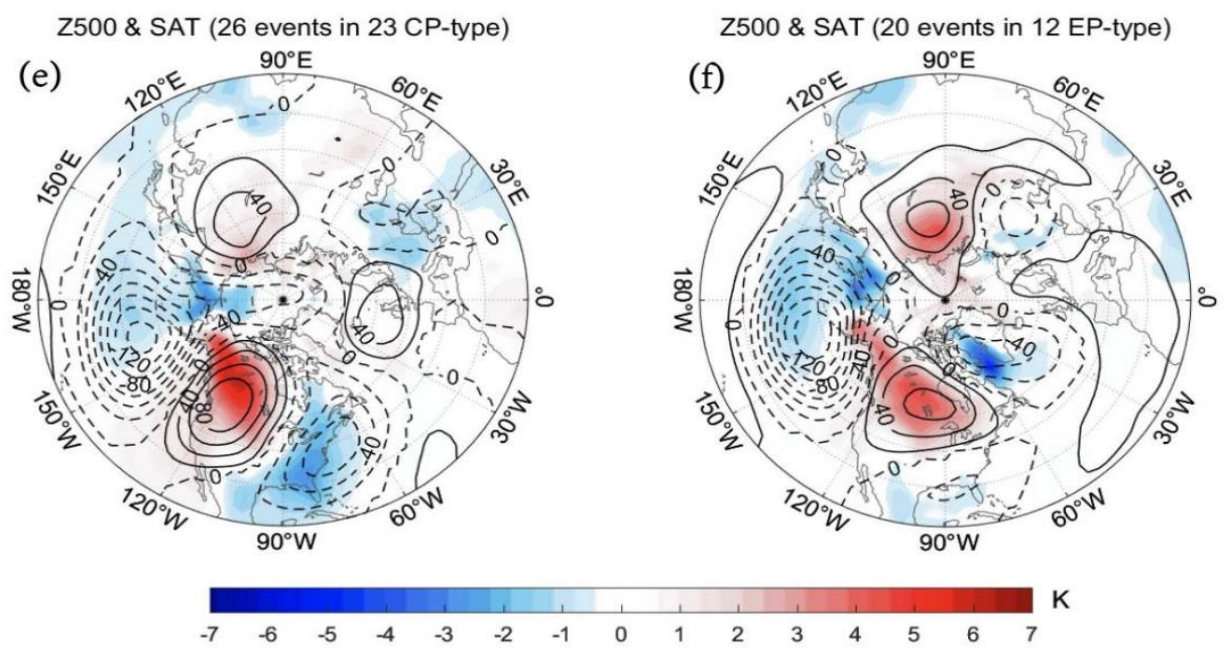

Figure 10. The first EOF (EOF1) mode of the Pacific SST anomaly based on the combined EOF-regression method for (a) CP- and (b) EP-type El Niño winters during 1950-2018. Normalized time series of the first principal component (PC1) of the Pacific SST EOF1 mode for (c) CP- and (d) EP-type El Niño winters. (e, f) Time-mean fields of composite daily Z500 (contours, $\mathrm{CI}=20 \mathrm{gpm}$ ) and SAT (color shading and unit: $\mathrm{K}$ ) anomalies averaged from lag-5 to 5 days of $\mathrm{PNA}^{+}$events during (e) CP- and (f) EP-type El Niño winters whose indices exceed 0.5 STDs, and the region of the SAT anomaly

733 (color shading) with the 95\% confidence level based on a two-sided Student's t-test is 734 plotted. 

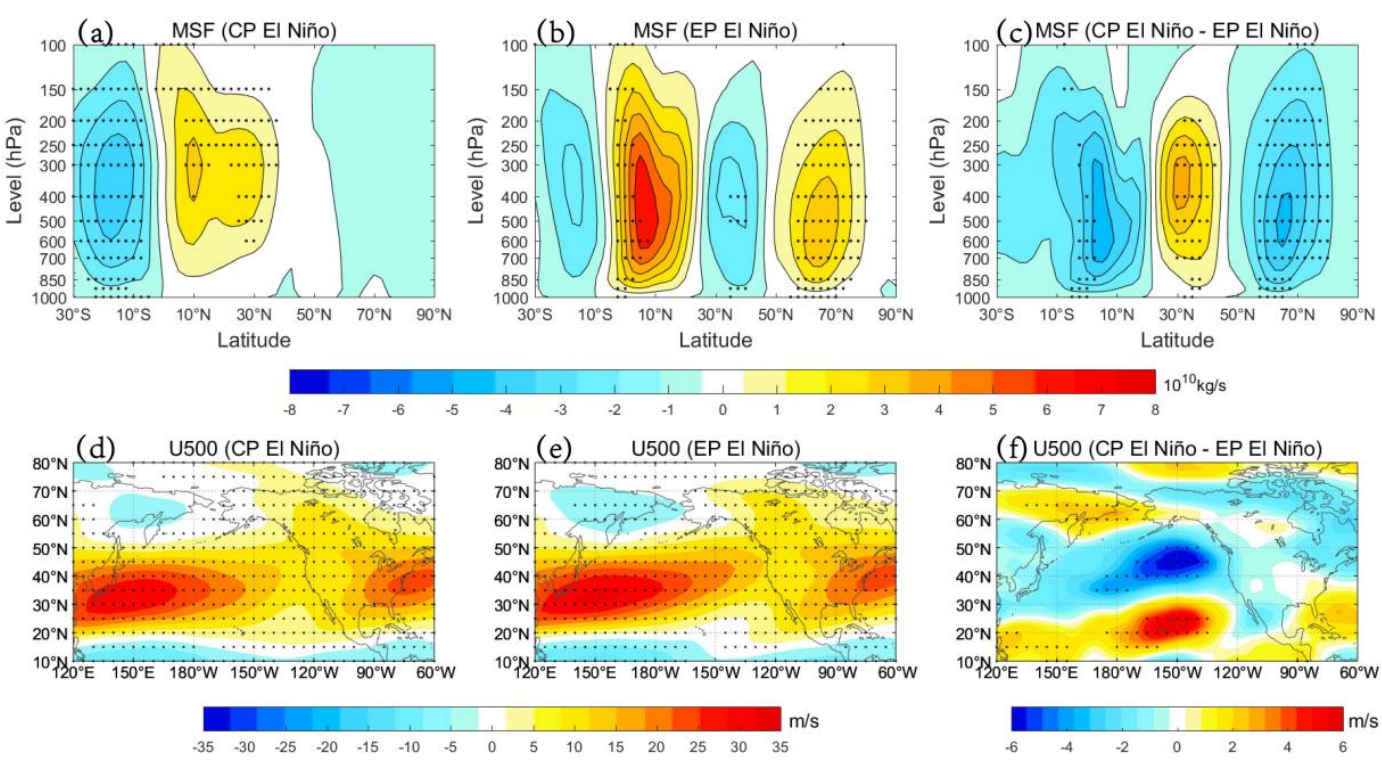

737 Figure 11. (a, b, c) Height-latitude profiles of composite DJF-mean mass stream

738 function (MSF) $\left(10^{10} \mathrm{~kg} \mathrm{~s}^{-1}\right)$ anomalies averaged over $150^{\circ} \mathrm{E}-120^{\circ} \mathrm{W}$. (d, e, f) Horizontal

739 fields of composite DJF-mean U500 $\left(\mathrm{m} \mathrm{s}^{-1}\right)$ for the PNA events excluded (the days of

740 the PNA event from lag -10 to10 days are removed) during (a, d) CP- and (b, e) EP-

type El Niño winters and (c, f) the CP-type minus EP-type El Niño difference. The dot

742 represents the region being the $95 \%$ confidence level based on a two-sided Student's t-

743 test. 
(a) PDO
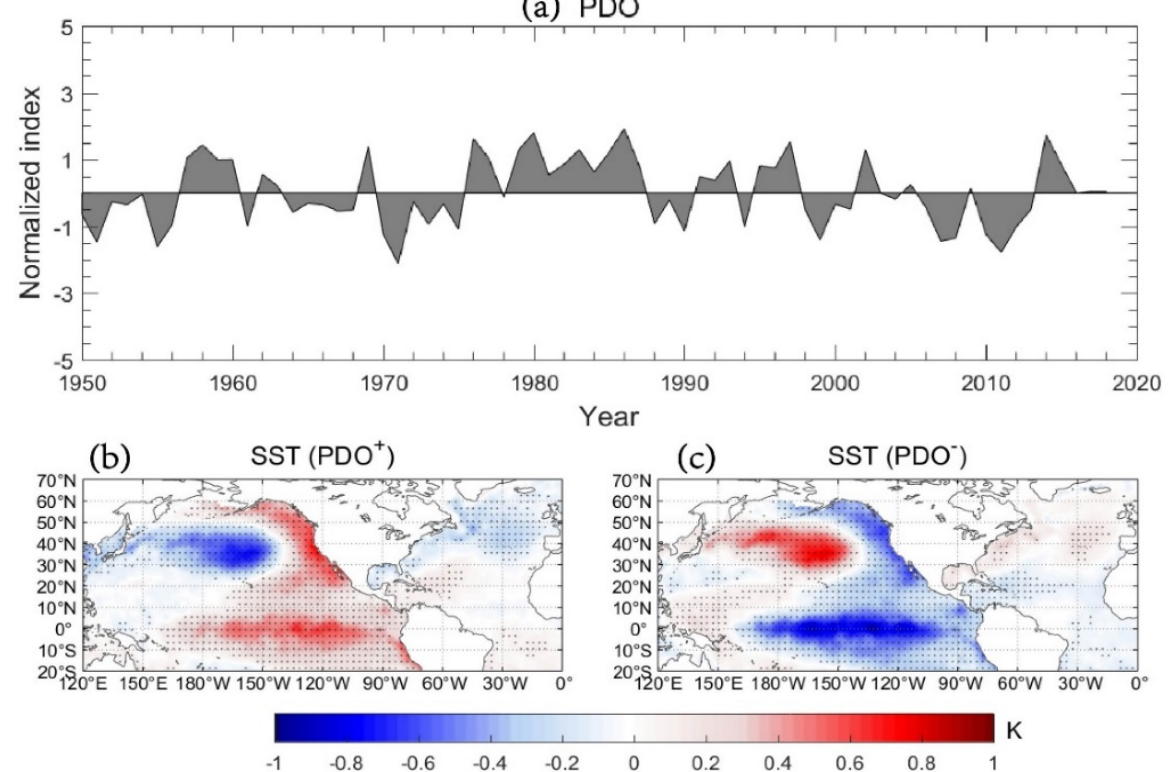

Z500 \& SAT (37 events in $24 \mathrm{PDO}^{+}$)
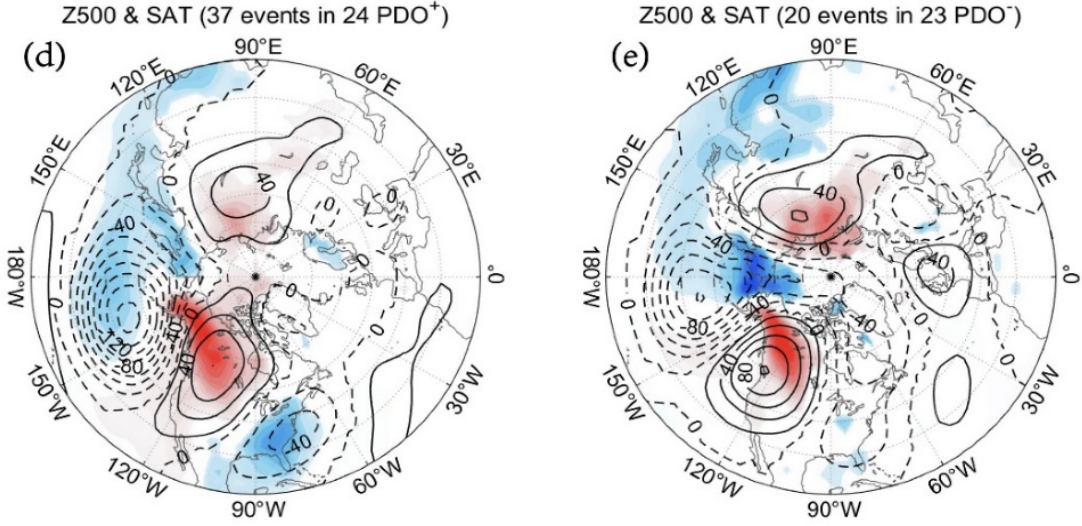

Figure 12. (a) Time series of normalized winter PDO index. (b, c) Composite DJFmean SST anomalies and (d, e) time-mean fields of composite daily Z500 (contours, $\mathrm{CI}=20 \mathrm{gpm}$ ) and SAT (color shading and unit: K) anomalies averaged from lag -5 to 5 days of $\mathrm{PNA}^{+}$events during $\mathrm{PDO}^{+}$and $\mathrm{PDO}^{-}$winters based on (a) positive (negative) phase of the PDO index above 0.5 STDs (below -0.5 STDs). In panels b-c, the dot represents the region being the 95\% confidence level for a two-sided Student's t-test, whereas the region of the SAT anomaly (color shading) with the $95 \%$ confidence level based on a two-sided Student's t-test is only plotted in panels d-e. 

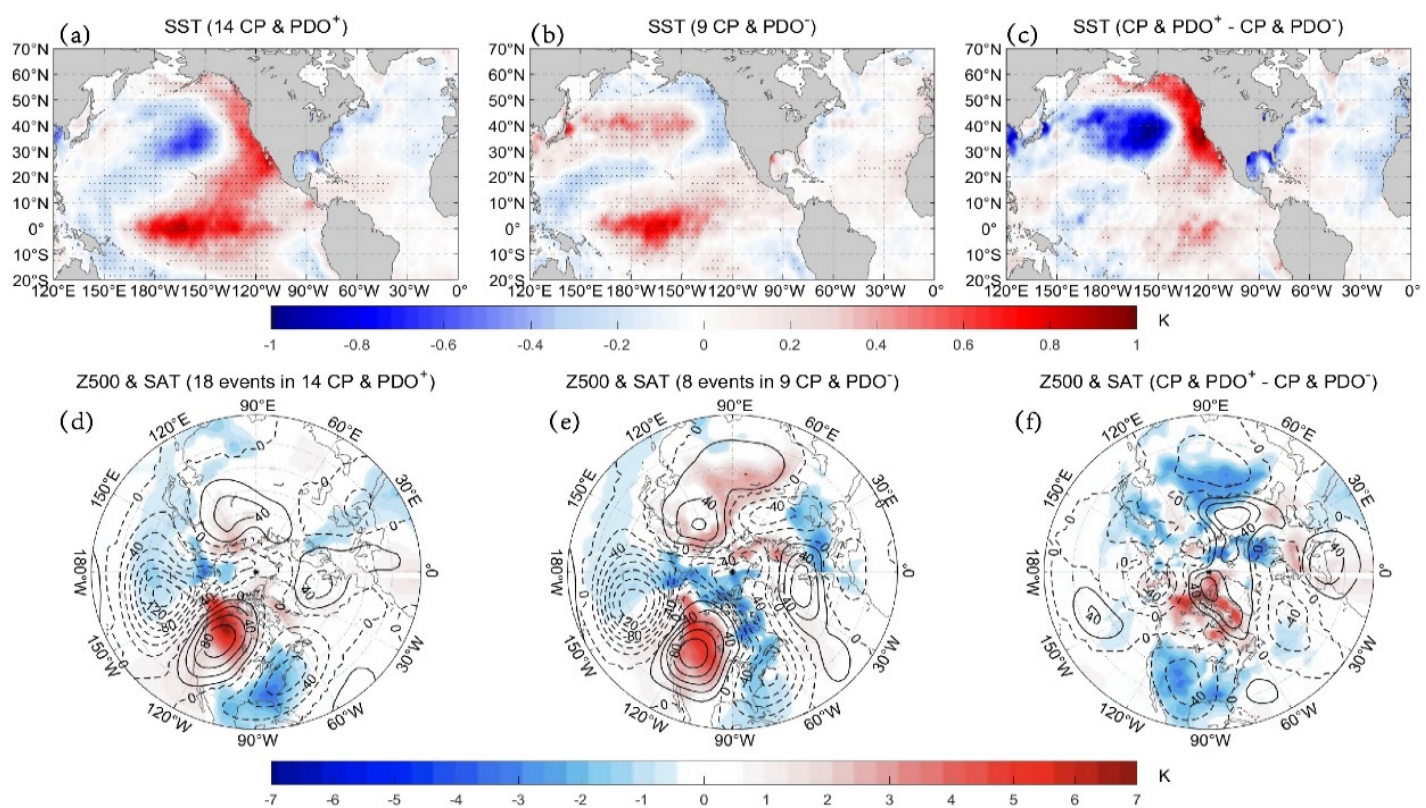

Figure 13. ( $a, b, c)$ Composite DJF-mean SST (color shading and unit: K) anomalies and (d, e, f) time-mean fields of composite daily Z500 (contours, CI=20 gpm) and SAT (color shading and unit: K) anomalies averaged from lag -5 to 5 days of $\mathrm{PNA}^{+}$events for the (a, d) $\mathrm{PDO}^{+}$and CP-type El Niño combination, (b, e) $\mathrm{PDO}^{-}$and CP-type El Niño combination and $(\mathrm{c}, \mathrm{f})$ their difference. The CP-type El Niño and $\mathrm{PDO}^{+}$combination is

761 defined as being a winter with the CP index above 0.5 STDs (Fig. 10c) and PDO index above 0 (Fig. 12a). Similarly, the CP-type El Niño and $\mathrm{PDO}^{-}$winter is defined as being a winter with the CP index above 0.5 STDs (Fig. 10c) and PDO index below 0 (Fig.

764 12a). In panels a-c, the dot represents the region being the $95 \%$ confidence level for a 765 two-sided Student's t-test, but in panels d-f the region of the SAT anomaly (color shading) with the $95 \%$ confidence level based on a two-sided Student's t-test is plotted. 


\section{Supplementary Files}

This is a list of supplementary files associated with this preprint. Click to download.

- supplementaryfile.docx 